\title{
An Evaluation of Limited Publication in the United States Courts of Appeals: The Price of Reform*
}

\author{
William L. Reynolds† \\ William M. Richmant†
}

In recent years, the caseload of the federal appellate courts has grown alarmingly in both the number of filings and the complexity of the issues presented for decision. In an effort to cope with the pressures created by those increases, the courts have modified the manner in which they process cases in a number of ways. Some changes, such as prehearing settlement conferences, ${ }^{1}$ have relatively little impact on the nature of the judicial process. The effect of others, such as reduction in oral argument, ${ }^{2}$ is more significant, for they alter the traditional method of judging appeals in ways that may substantially reduce the quality of appellate justice.

One of the most dramatic of the recent innovations is the adoption by many courts of rules that determine which opinions should be released for publication. ${ }^{3}$ In establishing criteria for pub-

* This study was sponsored by the Federal Judicial Center, Contract No. 9504-61017092-13. The views expressed herein do not necessarily represent the views of the Center.

We wish to thank a number of persons for their assistance in this project. Alan Chaset and Pat Lombard of the Federal Judicial Center and David Gentry of the Administrative Office provided us with data and the background to understand it. Toni Sommers of the University of Toledo provided invaluable assistance with statistical computation. David Aemmer of the Ohio Bar, Lawrence Haislip of the Maryland Bar, and Susan Roesler, University of Toledo College of Law class of 1982, provided research assistance. All unpublished opinions discussed in this article are on file with The University of Chicago Law Review.

$\dagger$ Professor of Law, University of Maryland.

i† Associate Professor of Law, University of Toledo.

- See, e.g., Goldman, The Civil Appeals Management Plan: An Experiment in Appellate Procedural Reform, 78 Couum. L. REv. 1209 (1978); Note, The Minnesota Supreme Court Prehearing Conference-An Empirical Evâluation, 63 MinN. L. REv. 1221 (1979).

2 See generally 2 Advisory Council for Appenlate Justice, Appellate Justice: 1975, at 2-32 (1975) [hereinafter cited as Appellate Justice].

8 This article discusses publication only in the United States Courts of Appeals. Many state courts also have adopted positions concerning unpublished opinions, sometimes arousing a good deal of controversy. See generally Kanner, The Unpublished Appellate Opinion: Friend or Foe?, 48 CAL. ST. B.J. 386 (1973); Newbern \& Wilson, Rule 21: Unprecedent and the Disappearing Court, 32 ARK. L. RBv. 37 (1978).

On the question of publication generally, see P. Carrington, D. MEador \& M. RosenBerg, Justice ON APPEAL 31-41 (1976); Chanin, A Survey of the Writing and Publication of 
lication the courts have been truly innovative; in spite of the pivotal role of the published judicial opinion in the development of American common law, the selection of cases for publication has rarely been the subject of publicly delineated criteria. The recent formal decisions not to publish large numbers of opinions have aroused concern that the quality of the work produced by the courts will be adversely affected. That concern has in turn led to considerable discussion of the merits and demerits of a formally organized regime of limited publication. ${ }^{4}$ Although the discussion has been rich in theory, it has been relatively poor in data. ${ }^{5}$

This article attempts to fill that gap. It presents an empirical assessment of the workings of the publication plans of the eleven United States Courts of Appeals during the 1978-79 Reporting Year. This is the first system-wide analysis of these publication plans and their effect on judicial productivity and responsibility. The article begins with a review of the background of publication plans. Then, after noting the methods used in the study, we analyze the relation between the language of the plans and the publication rates of the several circuits. Next comes an empirical assessment of the costs and benefits of limited publication. Finally, we propose a Model Rule for publication, designed to realize the benefits of limited publication while avoiding some of its hazards.

Opinions in Federal and State Appellate Courts, 67 LAw LIB. J. 362 (1974); Joiner, Limiting Publication of Judicial Opinions, 56 Judicature 195 (1972).

- The authors of this article have written on limited publication in two other places: Reynolds \& Richman, The Non-Precedential Precedent-Limited Publication and No-Citation Rules in the United States Courts of Appeals, 78 CoLum. L. REv. 1167 (1978) [hereinafter cited as Non-Precedential Precedent]; Reynolds \& Richman, Limited Publication in the Fourth and Sixth Circuits, 1979 Duke L.J. 807 [hereinafter cited as Limited Publication].

A bibliography on publication in federal appellate courts would also include the following: Hearings Before the Commission on Revision of the Federal Appellate Court System (2d phase 1974-75) [hereinafter cited as Hearings]; Gardner, Ninth Circuit's Unpublished Opinions: Denial of Equal Justice?, 61 A.B.A.J. 1224 (1975); Note, Unreported Decisions in the United States Courts of Appeals, 63 Connell L. Rzv. 128 (1977); Comment, A Snake in the Path of the Law: The Seventh Circuit's Non-Publication Rule, 39 U. PrTT. L. REv. 309 (1977).

There have been several publications that, while not empirical, are at least anecdotal. They review the unpublished opinions of a particular court and argue that some or many of them should have been published. See, e.g., Gardner, supra note 4; Comment, supra note 4. Limited Publication, supra note 4, is an empirical study but it is limited in scope, covering only two circuits and decisions over roughly three months. See also Remarks of John P. Frank, Ninth Circuit Judicial Conference (July 29, 1976) (unpublished study of 50 unpublished opinions) (on file with The University of Chicago Law Review). 


\section{BACKground}

\section{A. A Perspective on Publication}

In order to appreciate the importance of the limited publication debate, it is necessary to understand both the role of publication in American law, and past publication practice. The reasoned, published appellate opinion is the centerpiece of the American judiciary's work. The reasons for that prominence are not hard to understand, for they inhere in the role of appellate judges in a system of common law.

The rule of precedent is fundamental to the common law. ${ }^{6}$ In order to ensure consistency, judges explain why they decided as they did and why apparently similar cases were not thought to be controlling. Because opinions make law, these explanations must be readily accessible to interested persons. Their public availability is necessary to guide both the persons who may be affected by the law, and the judges who will apply that law to future disputes. The opinions of appellate courts naturally have special significance because of their position in the judicial hierarchy, and because the workload of nisi prius courts has made it increasingly difficult for them to issue polished opinions that contribute to the growth of the law.

Against this background, it is surprising that the expectation of a reasoned and published decision is a relatively recent one. Viewed in historical perspective, limited publication is hardly a radical idea; until recently, case reporting has been a haphazard enterprise. English cases have been officially reported only since $1865,{ }^{7}$ following a long history of selective reporting by legal entrepreneurs. ${ }^{8}$ Similarly, American reporting, virtually unknown until

- The propositions in this paragraph should, of course, be familiar to every American lawyer. See generally H. Hart \& A. Sacks, Thr Legal Process: Basic Problzms in the Making and Application of Law (tent. ed. 1958); Holmes, The Path of the Law, 10 Harv. L. Rev. 457 (1897); Wechsler, Toward Neutral Principles of Constitutional Law, 73 HARv. L. REv. 2 (1959). One of the authors of this article has set forth his views on the subject in more detail in W. Reynolds, Judicial Process in a Nutshell (1980).

"See generally R. WalkgR \& M. Walker, The English Legal SyStem 139-41 (4th ed. 1976), which criticizes the entire reporting system for its "informality." Official English reporting today produces the Law Reports under the aegis of the Incorporated Council of Law Reporting for England and Wales. There also are unofficial reporters, the most familiar of which is the All England Law Reports.

- The first English reports are the Year Books, which began, perhaps as a kind of early legal newspaper, in the reign of Edward I. See T. PluckNeTT, A Concise History op THB Common Law 269 (5th ed. 1956). Private reporting developed with the end of the Year Books in 1537. The quality of the private reports varied greatly. Holdsworth called Sir 
the start of the nineteenth century, ${ }^{9}$ was long the province of private venturers. Indeed, private reporting continued in at least some federal courts until well after the Civil War. ${ }^{10}$ These publications only gradually came to reflect an appreciation shared by judge and reporter concerning the form and content of the report." Today, of course, legal reporting is dominated by the West

James Burrow (1701-1782) the "connecting link" between "old" and modern reporting because Burrow strove for completeness and accuracy. 12 W. HoldsworTH, A History of ENGLISH LAW 110-12, 116 (1938).

- Apparently there is no general work on the history of publication in the United States. Ephraim Kirby's 1789 volume of Connecticut Reports was the first reporter published in this country, see L. FriEdman, A History of AmERICAN LAw 282 (1973), although modern historians have unearthed and published reports of colonial cases. See, e.g., D. Boorstin, Delaware Cases 1792-1830 (1943); Proceedings of the Maryland Court of ApPEALS 1695-1729 (C. Bond ed. 1933). Hence the comment, "Historians actually know more about colonial case law today than could have been widely known in colonial America." Johnson, John Jay: Lawyer in a Time of Transition, 1764-1775, 124 U. PA. L. REv. 1260, $1264 \mathrm{n} .17$ (1976). Another example of early publication is found in Maryland, where a court reporter and a young attorney began publishing colonial Maryland cases as a private venture in 1809. See C. Bond, The Courts or Apipeals of Maryland: A History 111 (1928). In contrast, publication in Massachusetts began with authorization from the legislature in 1804. W. Nelson, Americanization of the Common Law 168 (1975). Publication of New York cases began in 1794. Johnson, supra, at 1264 n.17.

Publication of Supreme Court opinions did not begin until the second volume of Dallas's Reports was published in 1798 . Even then progress lagged; although the third volume appeared in 1799, the fourth was held up until 1807. Other sources for Supreme Court work, such as newspapers, apparently were unsatisfactory. See J. GoEBEL, ANTECEDENTS AND BEGINNingS To 1801, at 664-65 (History of the Supreme Court of the United States, vol. 1, 1971).

10 Samuel Blatchford, both district and circuit judge before joining the Supreme Court, reported Second Circuit decisions until 1887 when the Federal Reporter, begun several years earlier, put him out of business. See M. Schick, LeARned Hand's Court 44 (1970).

${ }^{11}$ When Roger Taney became Chief Justice, for example,

[t]here was widespread disagreement . . . as to the subject matter to be included in the reports . . . . The question was much discussed in law journals. . . Reviewers varied all the way from those who wanted to save money for lawyers by limiting publication to selected opinions, to those who advocated publication of all opinions together with arguments of counsel and other relevant documents.

C. Swisher, The Taney Period, 1835-64, at 296 (History of the Supreme Court of the United States, vol. 4, 1974).

Standards were quite lax, even for Supreme Court reporting. Errors abounded, and sometimes the reporter failed to include dissenting opinions. Id. at 300-02. Justice Story found it commendable that reporters corrected grammatical and typographical errors. See id. at 299-300. Benjamin Howard, in the first volume of his Reports (1843), "resorted to what seemed an amazing example of bad taste by advertising his availability for the argument of cases." Id. at 308.

Uneven reporting required that both state and federal reports be regularly reviewed in the law reviews for quality and coverage. See, e.g., 8 AM. L.J. 273 (1848) (New Jersey); 1 AM. L. REg. 60 (1853) (Second Circuit).

Full and accurate reporting depended upon the development of a tradition of full and complete judicial explication of the decision. This is a relatively recent development. Lord 
Publishing Company. It routinely publishes all opinions sent to it by the circuit judges in accordance with their respective publication plans. ${ }^{12}$

Limited publication, then, is not new. What is new and radical is the notion that the judges themselves should be controlling access to their work by means of systematic publication plans. The publication plans of the federal courts of appeals collectively represent the most ambitious systematic effort to reconcile the conflict between the costs and benefits of full publication.

\section{B. The History of the Circuit Plans}

The movement toward the present circuit court publication plans began in 1964, when the Judicial Conference of the United States recommended that the federal courts authorize "the publication of only those opinions which are of general precedential value."13 Eight years later, ${ }^{14}$ the Board of the Federal Judicial Center proposed that each Circuit Council establish plans that

Coke advised that "wise and learned men do before they judge labour to reach to the depth of all the reasons of the case in question, but in their judgments express not any." 3 Co. Rep. v (J. Thomas ed., London 1826).

A look through state reports around 1800 reveals what to the modern reader is a startling lack of explication among courts of last resort. In Maryland, for example, the Court of Appeals often decided cases without an opinion until a statute requiring them was enacted in 1832. Lower courts were more prone to give reasons in order that their decisions could be properly reviewed on appeal. C. BoND, supra note 9, at 139-40.

By the mid-nineteenth century, however, a number of states had imposed, either through their constitutions or by statute, a requirement that appellate decisions be rendered in a written opinion. See Radin, The Requirement of Written Opinions, 18 Calir. L. REv. 486 (1930). That such development might not be wholly salutary was foreseen by Jonathan Swift:

It is a maximum [sic] among these lawyers, that whatever hath been done before may legally be done again; and therefore they take special care to record all the decisions formerly made against common justice and the general reason of mankind. These, under the name of precedents, they produce as authorities, to justify the most iniquitous opinions; and the judges never fail of directing accordingly.

J. Swirt, Gulliver's Travels 283 (Modern Library ed. 1931) (1st ed. London 1726).

12 West publishes only opinions designated for publication by the several circuits. Letter to authors from James P. Corson, Managing Editor, West Publishing Co. (May 23, 1980) (on file with The University of Chicago Law Review). Several federal courts (e.g., the Tax Court, the Court of Military Appeals) have their own reporter; the Courts of Appeals do not.

Unpublished opinions may be "published" in other sources, such as specialty reporters, or placed in the memory of a computerized legal research system such as LEXIS, see text and note at note 30 infra.

13 [1964] Judicial Conference of the United States Report 11.

14 Some of the circuits, in the meantime, had made some pronouncements in case law on the problem of unlimited publication. E.g., Jones v. Superintendent, Va. State Farm, 465 F.2d 1091 (4th Cir. 1972). 
would limit publication and forbid citation of unpublished opinions. ${ }^{15}$ Later that year, the Judicial Conference endorsed the Center's proposal and directed each circuit to devise a publication plan. ${ }^{16}$ In 1974, the Center published a Model Rule for publication, ${ }^{17}$ a proposal that has been the model for the publication plans of a number of circuits. Meanwhile, the circuits, responding to the Judicial Conference directive, had each sent a proposed publication plan to the Conference. The Conference applauded the diversity of these plans, for it meant that there would be "11 legal laboratories accumulating experience and amending their publication plans on the basis of that experience."18 Little has changed since

15 Board of the Federal Judicial Center, Recommendation and Report to the April 1972 Session of the Judicial Conperence of the United States on the Publication of Courts of Appeals Opinions (1972). The various groups mentioned in the text are described in more detail in Non-Precedential Precedent, supra note 4, at 1170-71 \& nn. 18, $25,26$.

16 [1972] Judicial Conference of the Unted States Report 33.

17 Advisory Council for Appellate Justice, FJC Research Series No. 73-2, StanDards for Publication of Judicial Opinions (1973) [hereinafter cited as Standards]. The development of these Standards is discussed in more detail in Non-Precedential Precedent, supra note 4, at 1170-71 \& n.25. The Model Rule provides:

1. Standard for Publication

An opinion of the (highest court) or of the (intermediate court) shall not be designated for publication unless:

a. The opinion establishes a new rule of law or alters or modifies an existing rule; or

b. The opinion involves a legal issue of continuing public interest; or

c. The opinion criticizes existing law; or

d. The opinion resolves an apparent conflict of authority.

2. Opinions of the court shall be published only if the majority of the judges participating in the decision find that a standard for publication as set out in section (1) of this rule is satisfied. Concurring opinions shall be published only if the majority opinion is published. Dissenting opinions may be published if the dissenting judge determines that a standard for publication as set out in section (1) of this rule is satisfied. The (highest court) may order any unpublished opinion of the (intermediate court) or a concurring or dissenting opinion in that court published.

3. If the standard of publication as set out in section (1) of the rule is satisfied as to only a part of an opinion, only that part shall be published.

4. The judges who decide the case shall consider the question of whether or not to publish an opinion in the case at the conference on the case before or at the time the writing assignment is made, and at that time, if appropriate, they shall make a tentative decision not to publish.

5. All opinions that are not found to satisfy a standard for publication as prescribed by section (1) of this rule shall be marked, Not Designated for Publication. Opinions marked, Not Designated for Publication, shall not be cited as precedent by any court or in any brief or other materials presented to any court.

${ }^{18}$ [1974] Judicial Conference of the United States Report 12. While the Judicial Conference studied publication, the Commission on Revision of the Federal Court Appellate System (chaired by Senator Hruska) also looked at the problem. Although the Hruska Com- 
1974. Although the Judicial Conference left the circuits' publication plans in a state of experimentation, there has been little effort to assess the results of those experiments either by scholars ${ }^{19}$ or the federal judicial establishment. ${ }^{20}$

\section{The Pros and Cons of Limited Publication}

The justification for limited publication rests on three premises: first, there is no need to publish all opinions; second, full publication is costly; and third, judges can effectively determine when an opinion need be published. Each of those premises can be disputed. In addition, several distinct counterarguments can be advanced against limited publication. ${ }^{21}$

1. Dispute Settling and Lawmaking. Common law opinions have two functions: they settle disputes among litigants and, in doing so, sometimes make law. ${ }^{22}$ Not all opinions, even at the appellate level, make law. Opinions may only reaffirm well-settled principles. These, the argument runs, need not be published, for society has no real interest in them. Such decisions are important to the litigants, but not to anyone else.

This argument is flawed by its reliance on a view of judicial lawmaking as the statement of mechanical rules rather than principles extracted from the decisions of cases read in their factual context. When judicial lawmaking is viewed in that light, it can be seen that all decisions make law, or at least contribute to the process, for each shows how courts actually resolve disputes. Applica-

mission recommended the adoption of limited publication and noncitation plans, the Commission deferred to the Judicial Conference concerning details. Commission on Revision of the Federal Court Apperlate System, Structure and Internal Procedures: RecommenDations for Change 50-52 (1975) [hereinafter cited as HRUSKa REPORT]. The testimony of judges, lawyers, and academics before the Commission provides valuable insight on the question of selective publication and noncitation. See Hearings, supra note 4.

1s See text and notes at notes 3-5 supra.

so Indeed, even the useful Publication Plans Reports prepared by the Administrative Office of the United States Courts for the years 1973 through 1977 have been terminated, which suggests that the plans may have come to be considered permanent. The Publication Plans Reports were prepared for the Subcommittee on Federal Jurisdiction of the Committee on Court Administration of the Judicial Conference of the United States. See NonPrecedential Precedent, supra note 4, at 1173 n.34. As far as we know, these reports represent the only effort sponsored by the entire federal judicial establishment to evaluate the workings of the plans. The Ninth Circuit, however, did sponsor a limited study by John Frank of publication in that circuit. See Remarks of John P. Frank, supra note 5.

21 More detailed discussion of the material in this section can be found in Non-Precedential Precedent, supra note 4, at 1181-85, 1187-94, 1199-1204.

${ }^{22}$ See H. Hart \& A. SAcks, supra note 6, at 396-97. 
tions of general principles in specific contexts clarify the scope of the principles. At the same time, such applications demonstrate whether the principles are actually followed by judges in routine cases or are simply "paper rules," useful mainly for display. The unavailability of decisions thus reduces our ability to understand the principles relied on by the court.

2. The High Cost of Full Publication. The second premise of the argument for limited publication asserts that excessive costs are associated with full publication. Those costs fall into two categories, one linked to the preparation of an opinion, the other to its consumption.

Preparing opinions is a large part of a judge's workload. More time must be spent if the opinion will be published-to allow more proofreading and prose polishing, for example. More effort also is required to ensure that the opinion contains no loose language that can return to haunt the court in a later case. Eliminating these costs can help judges cope more effectively with heavy workloads with little or no diminution in the quality of justice dispensed. Or so the argument goes. Although the idea seems plausible it has never been verified empirically. ${ }^{28}$

The second part of the excessive cost argument focuses on the cost of full publication to the consumers of opinions. To American lawyers this is a familiar problem. "The endless search for factual analogy"24 runs up the bill of the conscientious attorney with little or no gain in the refinement of legal principles. Law libraries and their budgets are strained to the breaking point and beyond. The bar looks with envy upon England, where the reported case law fills but a few volumes a year. ${ }^{28}$ These are real concerns, yet it must be remembered that even cumulative opinions have value. They can suggest how firm a line of precedent may be, for example, or indicate problems in the application of articulated precedent, or even show the divergence of a rule from the expectations of those to whom it is addressed. Thus, value can be found in publishing any opinion; the real question is whether the associated costs are too high.

2s We know of only one effort to do so, and it is unreliable. See Non-Precedential Precedent, supra note 4, at $1183 \mathrm{n} .95$ (discussion of a study of time allocation in the Third Circuit); $c f$. text and notes at notes 59-67 infra (finding that evidence is at best inconclusive as to increased productivity).

24 STANDARDS, supra note 17 , at 17.

${ }^{2 s}$ In 1979 , for example, the All England Reports comprised three volumes. 
3. The Early Decision Not to Publish. Many of the cost savings associated with limited publication would be lost if judges made the decision not to publish only after the opinion had already been polished and made ready for public consumption. An early decision not to publish entails significant costs, however, for value inheres in the actual writing of the opinion. For many authors, writing about a subject helps them to develop their thought on the topic. Furthermore, if an opinion in support of a decision simply "will not write," the conscientious judge is forced to reconsider the decision. ${ }^{28}$ The danger here is that the decision not to publish will affect the reasoning or even the result.

Another major problem with an early decision not to publish centers on the ability of a court to predict, early in the judicial process, that its opinion will not make law. The ability of judges to do so is by no means self-evident. If the prediction process is imperfect, the legal community will have lost access to opinions it should see.

4. Further Arguments Against Nonpublication. Limited publication can be attacked even if the above premises prove true. First, limited publication reduces judicial responsibility by removing the constraints that stare decisis places upon the court. The concept of precedent cautions as well as governs. If an opinion is not to be published, unwise things may be said without fear that the corpus juris will be adversely affected. Judicial responsibility also may be diminished if courts use the nonpublication list as a respository for troublesome cases presenting issues the court does not wish to address in public. Again, nonpublication may permit judges to approach their jobs more routinely, without the real thought and effort that precedential decision making requires. The final counterargument to limited publication recognizes the role played by the availability of opinions in holding judges accountable for their actions. If "[s]unlight is said to be the best of disinfectants,"

5. A Word on Citation Practices. As part of their approach to limited publication, seven of the circuits prohibit citation to an unpublished opinion, and an eighth discourages the practice; only three circuits permit free citation of such opinions. ${ }^{28}$ The prohibi-

${ }^{28}$ Hearings, supra note 4, at 735 (testimony of Professor Terrance Sandalow). See also note 151 infra.

${ }^{27}$ L. Brandeis, Other People's Money 92 (1914).

${ }^{28}$ The seven rules prohibiting citation of unpublished opinions are D.C. CIR. R. 8(f); 
tion of citation is part and parcel of the limited publication approach, for without such rules its goals could easily be frustrated. If citation were freely permitted, both litigants and judges would be unable to realize the potential time savings from not having to read unpublished opinions. ${ }^{2 \theta}$ In addition, the prohibition on citation is necessary to prevent unfairness arising from the ability of well-heeled litigants to monitor, store, and use unpublished opinions more readily than other litigants. ${ }^{30}$

The perception in seven circuits that a noncitation rule is a necessary aspect of a limited publication plan therefore seems substantially accurate. We have doubts, however, about the efficacy of noncitation rules. The hidden problem is whether the judges and their staffs adhere to the rule. We have found few opinions referring to unpublished opinions, indicating at least facial compliance with the noncitation rule. Still, some uneasiness persists, based on the intuition that not everyone who is aware of how cases have been decided will refrain from using that knowledge in later litigation. Our concern centers on pro se civil rights and habeas corpus cases. To the judges and clerks who handle those appeals, reliance on unpublished decisions-_"non-precedential precedents"31 -must be inevitable. The caseload is large, and there is often a previous decision squarely on point that provides a tempting research tool. Yet many of these cases are frivolous and hence go

1sT CIR. R. 14; 2D CrR. R. 0.23; 6TH CIR. R. 11; 7TH CIR. R. 35(b)(2)(iv); 8TH CIR. R. app.; 9TH CrR. R. 21(e). Neither the Third nor the Fifth Circuit addresses the citation issue. Only the Tenth affirmatively permits citation, 10TH CIR. R. 17(c); opposing parties must be served with a copy of any unpublished opinions that will be used. The Fourth Circuit permits but discourages citation. 4TH CIR. R. 18(d)(ii)-(iii).

29 See Non-Precedential Precedent, supra note 4, at 1186-87. This is especially true given the publication of "unpublished" opinions in unofficial specialty reporters and the recently developed computer systems such as LEXIS, making thęm available for general use if citation is permitted.

so Id. at 1187. The ability of courts to control circulation of unpublished opinions has been greatly diminished by the advent of computer-assisted legal research. Although the LEXIS memory bank purportedly contains only "publishable" opinions, see letter from Buzz Reed, Mead Data Central (Apr. 25, 1981) (on file with The University of Chicago Law Review), several of the unpublished opinions discussed in this article are available on the system. See, e.g., Burrison v. New York City Transit Auth., No. 78-7536 [603 F.2d 211] (2d Cir. Mar. 29, 1979); Moorer v. Griffin, No. 77-3580 [586 F.2d 844] (6th Cir. Oct. 12, 1978); United States v. Vera, No. 77-5363 [582 F.2d 1281] (6th Cir. July 10, 1978). All of these cases appear in the Federal Reporter (2d), but only as parts of tables of unpublished opinions. These opinions are available only to those able to pay for the service. Such limited circulation exacerbates the problem of unequal access.

31 The phrase comes from Judge Robert Sprecher's testimony before the Hruska Commission. Hearings, supra note 4 , at 537 . 
unpublished..$^{32}$ The result may be reliance on a substantial research library or "issues file" that is unavailable to the litigants."

\section{A Necessary Note on Workload}

The following sections analyze various problems associated with limited publication plans. Reflection upon those issues must include consideration of the difficulties that led the courts to adopt the publication plans: the increases in the volume and complexity of the work of the federal courts.

Apocalyptic commentaries on the workload of the United States Courts of Appeals are not hard to find. ${ }^{34}$ Their very familiarity may rob them of some of their impact. Examination of the product of the circuit courts over even a short period lends some perspective, dramatically bringing home the overload.

This study covered the year ending June 30,1979 . In that time, the eleven circuits terminated 12,419 cases following judicial action. ${ }^{35}$ During that period there were 97 circuit judges. ${ }^{38}$ On average, each of those judges decided about 1.2 cases per working day. ${ }^{37}$ For each vote a participating judge must have done some

32 See text at note 148 infra for the tendency to permit a disproportionate number of opinions in such cases to go unpublished.

ss Hearings, supra note 4, at 537 (testimony of Judge Sprecher).

34 A sample of these alarming recitations can be found in NLRB v. Amalgamated Clothing Workers, 430 F.2d 966 (5th Cir. 1970); HRUSKA RRPORT, supra note 18, at 55; Haworth, Screening and Summary Procedures in the United States Courts of Appeals, 1973 WASH. U.L.Q. 257.

35 That figure is obtained from statistical data supplied by the Administrative Office of the United States Courts (Sept. 24, 1980) (on file with The University of Chicago Law Review) [hereinafter cited as Statistical Data], by adding the totals from Tables IP (total published opinions) and 5U (total unpublished opinions). See note 45 infra for explanation of the term "with judicial action." The total number here does not include consolidations, i.e., cases that have separate docket numbers but are briefed, argued, or decided with other cases in one proceeding. Including consolidations the total is 15,053. (Consolidations estimated as $17.5 \%$ of the total number of cases terminated, in accord with ADMINISTRATIVE Office of the United Statzs Courts, 1979 Annual Report of the Director 51 [hereinafter cited as Annual Report].)

36 The actual number of authorized judgeships in the United States Circuit Courts was 132, but 35 judgeships were unfilled. See ANNuAL REPORT, supra note 35, at 44.

37 The 1.2 figure was computed as follows: Because circuit judges typically sit in panels of three, in order to determine the total number of judicial votes cast to decide the 12,419 cases, that figure must be multiplied by three; thus there were 37,257 votes cast during the fiscal year. Of those votes, $77.8 \%$ were cast by active circuit judges (the others were cast by visiting and by senior circuit judges, see id. at 50), a total of 28,986. Assuming 250 working days for each of the 97 active circuit judges, the total number of "judge-days" in fiscal 197879 was 24,250 . Simple division then shows that the average active circuit judge decided almost 1.2 cases per day. (It should be noted that in some proceedings, motions to reduce or 
reading and research. ${ }^{38}$ If all he read were the briefs, staff memoranda, and record in each case, his workdays would be full. In addition, the judge must draft opinions for publication, read the drafts of other judges' opinions, participate in conference, and hear arguments. Each judge must try to keep current on developments in the law, run his staff, help administer his circuit, perhaps serve on professional committees, and so on.

The point of this fairly dreary exposition is that the object of this article is not to criticize the judges. Their dedication and industry is beyond question. We aim only to examine and evaluate one technique that judges have used to streamline their workload.

The next three parts of the article report the empirical study. We begin with a description of the methodology used in the study. We then examine the relation between publication frequency and the content of the several publication plans. Finally, we discuss the costs and benefits associated with limited publication: What do the judges gain from nonpublication? Are there any drawbacks associated with those gains? Are there ways to minimize the costs while realizing most of the gains?

\section{The Study: Methodology}

Our assessment of the impact of the publication plans on the decision-making process of the courts of appeals is based on a study of the published and unpublished opinions of those courts during the 1978-79 Reporting Year. ${ }^{39}$ Reviewing the material pub-

grant bail, for example, circuit judges may act singly. This means the average stated above is somewhat high.)

Average figures, of course, conceal peaks and valleys among the circuits. In the Fourth Circuit, for instance, 1236 cases were decided by judicial action. Multiplication by three yields a total of 3708 votes. Reducing that figure by $20 \%$ for votes cast by senior and visiting judges yields 2966 . Seven active judges provided 1750 judge-days over the assumed 250 working days, and thus nearly 1.7 decisions per day for each active circuit judge.

In the District of Columbia Circuit, by contrast, the number of cases decided after judicial action was 699 , producing 2097 total votes. This figure must be reduced by $20.7 \%$ to account for the contribution of visiting and senior judges. The result of that reduction, 1663, when divided by 2250 total judge-days ( 9 judges times 250 working days) yields nearly .74 decisions per judge per day. Percentages of votes cast by active circuit judges are from $i d$. at 51. Cases decided per circuit is computed from Statistical Data, supra note 35, Tables IP, $5 \mathrm{U}$.

ss Some cases naturally present fewer problems than others; many are frivolous. For a conscientious judge, however, even those present demands on his time. The judge who wishes to supervise even minimally the work of the staff attorneys and his own law clerks must spend some time on even the most frivolous appeal.

so The Reporting Year ran from July 1, 1978 through June 30, 1979. For the statistics 
lished during that period was relatively straightforward; we used all appeal-dispositive documents-"opinions" eral Reporter (2d) for that year.11 Choosing the unpublished material involved somewhat more selectivity because the Administrative Office of the United States Courts (the administrative and record-keeping agency of the federal judiciary) distinguishes between appeals terminated "by judicial action" and those terminated "without judicial action." 42 We studied only the former group, because we did not want to include consent decrees, affirmances or reversals by stipulation, or out-of-court settlements. . $^{\text {s }}$ Those types of dispositions present only bookkeeping problems to the judges, and do not require any real exercise of judicial ability; their inclusion in the study, therefore, would obscure the nature of what judges in fact do. Accordingly, the total population for this study included all terminations that were published,44 and all unpublished terminations that were by "judicial action." 45 Table 1 records the population of published and unpublished opinions used in the study.

kept by the Administrative Office of the United States Courts for that period, see ANNuAL REPORT, supra note 35, at A-1 to -175 .

to "Opinion" is a generic term. The several circuits refer to their written products by many different (and at times inconsistent) labels. Included in the term "opinion" for our purposes are what some circuits would call opinions, memoranda, per curiam opinions, orders, judgments, and judgment orders.

"A list of "Appeals Terminations" was furnished us by the Administrative Office. All information compiled by the Office and, in turn, all the information that we used in the study was compiled from records kept by the individual circuit court clerks on a form known as "J.S. 34 Appeals Disposition-Termination Form" (on file with The University of Chicago Law Review) [hereinafter cited as J.S. 34]. In order to generate the list of published appeals terminations, we selected all terminations whose J.S. 34 forms contained checks in positions 1,2 , or 3 in box 13 ("Opinion").

42 See the J.S. 34 form, boxes 9 and 10 (termination 'by judicial action), and box 11 (termination without judicial action).

13 Nevertheless, we found a fair number of decisions labeled "judicial action" that were, in fact, voluntary dismissals and the like.

" A total of 4737 terminations were published. Thirty-eight terminated appeals were recorded as "published" but as not involving "judicial action"; we therefore excluded them from the study for reasons explained in text and note at note 43 supra. These inconsistent designations probably were the result of a reporting error. In any case, their number is insignificant.

45 This procedure differs from the Administrative Office's typical record-keeping habits in one important respect. For many purposes (e.g., recording reversal rates and separate opinion rates), the Office uses as its relevant total disposition population the set of appeals dispositions that occurred after oral hearing or submission upon the briefs. See, e.g., ANNUAL RePorT, supra note 35, Table B1. For most of the same purposes, we chose the larger population of appeals terminated "by judicial action." The difference between the two populations is that many cases docketed in the courts of appeals are terminated without argument 
TABLE 1

Published AND Unpublished Opinions

\begin{tabular}{lccr}
\hline Circuit & Published & Unpublished & Total \\
\hline D.C. & 194 & 505 & 699 \\
First & 214 & 147 & 361 \\
Second & 359 & 563 & 922 \\
Third & 219 & 991 & 1210 \\
Fourth & 346 & 890 & 1236 \\
Fifth & 1385 & 978 & 2363 \\
Sixth & 340 & 908 & 1248 \\
Seventh & 325 & 736 & 1061 \\
Eighth & 448 & 209 & 657 \\
Ninth & 618 & 1238 & 1856 \\
Tenth & 251 & 555 & 806 \\
\hline \multicolumn{1}{c}{ Total } & 4699 & 7720 & 12419 \\
\hline
\end{tabular}

Source: Statistical Data, supra note 35, Tables 1P, 5U.

or submission upon written briefs. Some of these nevertheless are terminations "by judicial action." Examples are motions for summary affirmance, motions for stays, and motions for bail reductions. These cases typically involve some written argument to the court; however, they are not reported as "submitted upon written briefs" unless the "brief" is the formal brief contemplated in FzD. R. APP. P. 28. Telephone conversation with David Gentry, Research Analyst, Administrative Office of the United States Courts (July 24, 1980). We reasoned that the larger population of appeals terminated "by judicial action" was more appropriate for our study than the smaller set of appeals terminated "after argument or submission" because the larger group more closely reflects the total case-terminating work of the judges.

In the course of our study, it became apparent that the total number of opinions indicated as unpublished on the J.S. 34 forms compiled by the Administrative Office included a few opinions that actually were published. This could be the result either of errors by the circuit court clerk in filling out the J.S. 34 forms, or of reversals of original decisions not to publish. Because it was impractical for us to verify independently that each of the nearly 8000 "unpublished" opinions on the list supplied by the Administrative Office was unpublished, we did not correct for these factors. We have no reason to believe that excluding these opinions would significantly decrease the population size, particularly because coding 


\section{Results of the Study: Publication Plans and Publication Performance}

The fundamental empirical question concerning the publication plans ${ }^{46}$ is whether they have any effect at all on the decision to publish. Do the judges actually pay attention to the plans? Fortunately for the analyst, both the contents of the publication plans and the extent to which publication is limited vary widely among the circuits. Differences occur along several lines-the specificity of publication criteria, the existence vel non of a presumption against publication, and the maker of the publication decision. ${ }^{47}$ This section examines the effect of those differences on the circuits' actual publication behavior. Table 2, which reports the percentage of published and unpublished opinions in each circuit, will facilitate that examination.

TABLE 2

Percentage of Opinions Puglished

\begin{tabular}{lcc}
\hline \hline Circuit & Published (\%) & Unpublished (\%) \\
\hline D.C. & 27.8 & 72.2 \\
First & 59.3 & 40.7 \\
Second & 38.9 & 61.1 \\
Third & 18.1 & 81.9 \\
Fourth & 28.0 & 72.0 \\
Fifth & 58.6 & 41.4 \\
Sixth & 27.2 & 72.8 \\
Seventh & 30.6 & 69.4 \\
Eighth & 68.2 & 31.8 \\
Ninth & 33.3 & 66.7 \\
Tenth & 31.1 & 68.9 \\
\hline \multicolumn{1}{c}{ Average } & 38.3 & 61.7 \\
\hline
\end{tabular}

Sourcz: Calculated from the data in Table 1 supra.

error presumably would be randomly distributed, with approximately equal numbers of unpublished opinions coded as published and published opinions coded as unpublished. 


\section{A. Specificity.}

One aspect in which the plans vary widely is the specificity of the standards that guide the publication decision. Some plans establish criteria that can only be described as vague. The Third Circuit, for example, prescribes publication only where "the opinion has precedential or institutional value." 48 Other circuits have specific publication criteria. The Ninth Circuit Plan, for example, provides for publication of an opinion that

(1) Establishes, alters, modifies or clarifies a rule of law, or

(2) Calls attention to a rule of law which appears to have been generally overlooked, or

(3) Criticizes existing law, or

(4) Involves a legal or factual issue of unique interest or substantial public importance, or

(5) Relies in whole or in part upon a reported opinion in the case by a district court or an administrative agency, or

(6) Is accompanied by a separate concurring or dissenting expression, and the author of such separate expression desires that it be reported or distributed to regular subscribers. ${ }^{40}$

16 All of the circuits have limited publication plans. In addition, all but one have local rules that address the question. A circuit's position on limited publication thus can be determined only by looking at both its plan and any relevant local rules. The following are the relevant rules: D.C. CIR. R. 8(f); 1st CIR. R. 14; 2D CIR. R. 0.23; 4TH CIR: R. 18; 5TH CIR. R. 21; 6TH CIR. R. 11; 7TH CIR. R. 35; 8TH CIR. R. 14; 9TH CIR. R. 21; 10TH CIR. R. 17. In the Second, Fourth, Seventh, Ninth, and Tenth Circuits, the publication plan consists simply of the text of the rule. In the Third Circuit, there is no relevant local rule, but only a publication plan. In the other five circuits, the publication plan is distinct from the local rule on the question. In two circuits, the First and the Eighth, the publication plans appear as appendices to the circuit's local rules.

47 Earlier, we attempted to classify the publication plans of the Fourth and Sixth Circuits as "conservative" and "radical," respectively. Those classifications were somewhat awkward, but they did permit consideration of these factors. We hypothesized that a radical plan would produce lower publication percentages than a conservative plan. The data did not support that hypothesis. See Limited Publication, supra note 4, at 810-14, for an explanation of the terms.

4 ThIrd Circuit Plan (on file with The University of Chicago Law Review).

19 9TH CIR. R. 21(b). 
The circuits can be roughly divided into two groups depending on the specificity of their publication criteria. ${ }^{50}$ Table 3 displays the circuits in that arrangement with the percentage of published and unpublished opinions produced by each circuit. The data show little correlation between the degree of specificity of a circuit's publication criteria and its actual publication behavior. The average publication percentage for circuits with detailed standards was $36.5 \%$ while the average for circuits with vague standards was $40.4 \%$. On the other hand, the data in Table 3 may give dispropor-

TABLE 3

Publication Related to Specifictiy of Standards

\begin{tabular}{|c|c|c|}
\hline \multicolumn{3}{|c|}{ Publication in Circutts with Vague Standards } \\
\hline Circuit & Published (\%) & Unpublished (\%) \\
\hline First & 59.3 & 40.7 \\
\hline Second & 38.9 & 61.1 \\
\hline Third & 18.1 & 81.9 \\
\hline Fifth & 58.6 & 41.4 \\
\hline Sixth & 27.2 & 72.8 \\
\hline Average & 40.4 & 59.6 \\
\hline \multicolumn{3}{|c|}{ Publication in Circutts with Spbcific Standards } \\
\hline Circuit & Published (\%) & Unpublished (\%) \\
\hline D.C. & 27.8 & 72.2 \\
\hline Fourth & 28.0 & 72.0 \\
\hline Seventh & 30.6 & 69.4 \\
\hline Eighth & 68.2 & 31.8 \\
\hline Ninth & 38.3 & 66.7 \\
\hline Tenth & 31.1 & 68.9 \\
\hline Average & 36.5 & 63.5 \\
\hline
\end{tabular}

so The circuits with "vague" standards, and the pertinent rules, are: 1st CrR. R. app. B; 2d Cir. R. 0.23; Third Circuit Plan para. (a); 5Th Cir. R. 21; Sixth Circuit Plan para. 2 (on file with The University of Chicago Law Review). The "specific" rules are: District of Columbia Crrcuit Plan para. e (on file with The University of Chicago Law Review); 4TH CIR. R. 18(a); 7TH CIR. R. 35(c)(1); 8TH CIR. R. app. para. 4; 9TH CIR. R. 21(b); 10TH CIR. R. 17(d), (e). 
tionate effect to the publication habits of the Eighth Circuit. All of the other circuits with specific standards have publication percentages in the high $20 \mathrm{~s}$ or low 30 s, or less than half the Eighth Circuit's publication percentage of $68.2 \%$. If the Eighth Circuit is excluded, the average percent published for the circuits with specific standards would be $30.2 \%$, and the percentage of opinions unpublished would be $69.8 \%$. These percentages would indicate that a substantially greater proportion of opinions are published in circuits with vague standards. Unless and until we discover some anomalous practice in the Eighth Circuit explaining the disparity, however, we do not feel justified in excluding the circuit from our computations. At any rate, we cannot be as confident as the results of Table 3 might warrant that specificity of standards has no effect on publication percentage. It may well be that vague standards enhance the likelihood of publication.

\section{B. Presumptions}

Another provision that might affect the tendency to publish is a presumption against publication. Some circuits make such a presumption explicit. The First Circuit Plan, for instance, provides that

While we do not presently attempt to categorize the criteria which should determine publication, we are confident that a significantly larger proportion of cases will result in unpublished decisions if the court adopts a policy of self conscious scrutiny of the publish-worthiness of each disposition coupled with a presumption, in the absence of justification, against publication..$^{\text {s1 }}$

In other circuits the presumption is not explicit, but is inferable. ${ }^{.2}$ In still other circuits there is no presumption against publication.

Commentators generally have favored publication plans with specific publication standards. The reason for that preference is not really the hope for lower published/nonpublished ratios. Rather, the commentators have believed that vague criteria might be an insufficient guide and that precedential opinions might be lost through misclassification. See Non-Precedential Precedent, supra note 4, at 1177; Note, supra note 4, at 147.

${ }^{\text {s1 }}$ Ist CIR. R. app. B(a).

62 The Fourth Circuit, for example, before listing its publication standards provides that "an opinion shall not be published unless it meets one of the following standards for publication." 4TH CRr. R. 18(a). 
A plausible hypothesis is that the circuits that have a presumption against publication (explicit or implicit) ${ }^{53}$ would publish less than circuits without such a presumption. Table 4 shows that circuits without presumptions against publication published $44.9 \%$ of their opinions, while circuits with such a presumption published only $32.7 \%$ of their opinions. The existence of a presumption against publication, then, does seem to affect actual publication practice. ${ }^{54}$

\section{TABLE 4}

Publication Related to Presumptions Against Publication

Circuits hith Pregumption Against Publication

\begin{tabular}{lcc}
\hline Circuit & Published (\%) & Unpublished (\%) \\
\hline First & 59.3 & 40.7 \\
Third & 18.1 & 81.9 \\
Fourth & 28.0 & 72.0 \\
Sixth & 27.2 & 72.8 \\
Seventh & 30.6 & 69.4 \\
Ninth & 33.3 & 66.7 \\
\hline Average & 32.7 & 67.3 \\
\hline
\end{tabular}

Circuits Wrthout Presumption Against Publication

\begin{tabular}{lcc}
\hline Circuit & Published (\%) & Unpublished (\%) \\
\hline D.C. & 27.8 & 72.2 \\
Second & 38.9 & 61.1 \\
Fifth & 58.6 & 41.4 \\
Eighth & 68.2 & 31.8 \\
Tenth & 31.1 & 68.9 \\
\hline \multicolumn{1}{c}{ Average } & 44.9 & 55.1 \\
\hline
\end{tabular}

${ }^{33}$ Six Circuits have a presumption against publication. See IsT CIR. R. app. B(a) (explicit); ThIRd CIRcuIT Plan paras. 1, 2 (with regard to per curiam opinions, but not with regard to signed opinions); 4TH CIR. R. 18(a) (implicit); SIXTh CircuIT PlaN para. 2 (explicit); 7TH CIR. R. 35(a) (explicit); 9TH CIR. R. 21(a), (b) (implicit).

st There are, of course, other possible explanations for these variations. It should be noted that in general the circuits with presumptions against publication are larger than the circuits without such presumptions. (See the figures in Table 1 supra.) The size of the circuit and the accompanying administrative burdens may have an effect on the judges' tendency to publish. Some doubt is cast on this proposition by the high publication percentage 
3. Who Makes the Decision. Frequency of publication also might be affected by who makes the publication decision. Some circuits require a majority decision to publish, ${ }^{55}$ while others permit a single judge to require publication. ${ }^{56}$ It is plausible that circuits that permit a positive publication decision by a single judge would publish a higher percentage of their opinions than circuits that require a majority. Table 5 provides only mild support for TABLE 5

Publication Related to Decision to Publish

Circuits That Require a Majority por a Decision to Publish

\begin{tabular}{lcc}
\hline Circuit & Published (\%) & Unpublished (\%) \\
\hline First & 59.3 & 40.7 \\
Third & 18.1 & 81.9 \\
Seventh & 30.6 & 69.4 \\
Ninth & 33.3 & 66.7 \\
Tenth & 31.1 & 68.9 \\
\hline \multicolumn{1}{c}{ Average } & 34.5 & 65.5 \\
\hline
\end{tabular}

Crrcuits That Permit a Decision to Publish by a Single Judge

\begin{tabular}{lcc}
\hline Circuit & Published (\%) & Unpublished (\%) \\
\hline D.C. & 27.8 & 72.2 \\
Second & 38.9 & 61.1 \\
Fourth & 28.0 & 72.0 \\
Fifth $^{\mathrm{a}}$ & 58.6 & 41.4 \\
Sixth & 27.2 & 72.8 \\
Eighth & 68.2 & 31.8 \\
\hline \multicolumn{1}{c}{ Average } & 41.4 & 58.6
\end{tabular}

a Although 5TH CIR. R. 21 does not explicitly address the issue, it has been construed as requiring a unanimous decision not to publish. See NLRB v. Amalgamated Clothing Workers, 430 F.2d 966, 972 (5th Cir. 1970).

that the largest circuit, the Fifth, displays. Because the Fifth Circuit is also the only one of the six largest circuits without a presumption against publication, its high publication percentage seems to support the conclusion in the text.

ss See 1st CIR. R. app. B(b)(4); Third Circuit Plan paras. 1, 2; 7Th CIR. R. 35(d)(1); 9TH CIR. R. 21(d); 10TH CIR. R. 17(c).

so See District or Columbia Circuit Plan; 4TH Cir. R. 18(b) (author or majority de- 
that hypothesis. The one-vote circuits publish an average of $41.4 \%$ of their opinions, while majority-vote circuits publish $34.5 \%$. It is difficult to assume any sort of causal connection from such a small differential. ${ }^{.57}$

\section{Results of the Study: An Empirical Assessment of Costs AND BENEFITS}

\section{A. Benefits}

The major impetus for the limited publication movement has been the dramatically increasing caseload of the circuit courts. Limited publication can help the judges to deal with the glut, it is argued, because an unpublished opinion takes much less judicial time and effort to prepare than a published opinion. ${ }^{58}$ If nonpublication does result in significant savings, those savings should be revealed in two ways: swifter justice and increased judicial productivity.

1. Swifter Justice. If justice delayed is justice denied, then swifter justice obviously is an important goal. At the appellate level, the speed of justice can be measured by the number of days between the time at which the record was complete and the date of

cides); Stxth Circutt Plan para. 2; 8Th CIR. R. app. para. 3. See also 2D Cir. R. 0.23 (requiring a unanimous decision not to publish).

87 There are two other related issues. First, four circuits permit a judge who writes a separate opinion to publish even if a panel majority votes not to. DisTrict of Columbia CIRCUIT PLAN; 7TH CIR. R. 35(d)(2) (permitting, but advising against, such publication); 8TH CrR. R. app. para. 3; 9rH CIR. R. 21(b)(6). Those four circuits publish slightly more frequently than do the other seven ( $40 \%$ to $37.3 \%$, computed from the percentages in Table 2 supra). Because of the extreme scarcity of unpublished separate opinions, see text at note 131 infra, it is not surprising that these provisions have no significant effect on publication percentages. They may be useful, however, because they help ensure against arbitrariness on the part of a majority.

Second, two circuits will entertain requests by persons outside the court for publication of certain decisions. 7TH CIR. R. 35(d)(3); 9TH CR. R. 21(f). This, too, is a useful concept. Although we have suggested previously that the practice may favor institutional litigants, Non-Precedential Precedent, supra note 4, at 1178-79, that may not be the case. In the Seventh Circuit, 21 requests for publication from outsiders were received by the Seventh Circuit. The Court honored most of the requests, which came from a disparate group. Letter to authors from Thomas Strubbe, Clerk (Oct. 7, 1980) (on file with The University of Chicago Law Review). The Ninth Circuit has a variation authorizing staff law clerks to recommend the publication of appropriate decisions. Hellman, Central Staff in Appellate Courts: The Experience of the Ninth Circuit, 68 CALr. L. Rav. 937, 949-50 (1980). This practice appears to lead to a minimal increase in publication rates, if any. The two circuits allowing it publish $32.5 \%$ of their opinions, while the other nine publish $39.7 \%$.

so STANDARDS, supra note 17 , at 5 . 
the final judgment-turn-around time, for short. Table 6 suggests that nonpublication promotes swifter justice. As the table shows, turn-around time is considerably shorter if an opinion is not published. One out of every five unpublished opinions took no longer than three months to resolve, for example, but only one out of every thirty-three published cases was decided that quickly. Almost half of the unpublished opinions had a turn-around time of half a year or less; the comparable figure for published opinions was one-fifth.

TABLE 6

TiMe ror Decision

Turn-Around

Time (Days) a

Published (\%)

Unpublished (\%)

\begin{tabular}{lrr}
\hline $0-10$ & 0.3 & 3.8 \\
$11-30$ & 0.4 & 3.0 \\
$31-60$ & 1.0 & 6.4 \\
$61-90$ & 2.2 & 7.4 \\
$91-120$ & 3.8 & 7.8 \\
$121-150$ & 6.0 & 10.0 \\
$151-180$ & 6.9 & 9.9 \\
$181-360$ & 36.7 & 31.1 \\
360 or more & 42.6 & 20.7 \\
\hline
\end{tabular}

Source: Compiled from data on 11,487 cases disposed of during the 1978-1979 Reporting Year for which data were available. Statistical Data, supra note 35, Tables 6P, 6U.

a Measured by the interval between the day the record was complete and the date of final judgment.

Although there can be no doubt that cases culminating in unpublished opinions are resolved more quickly, it is impossible to determine how much of that saving can be attributed to limited publication. Much may be because unpublished litigation is easier to decide. By definition, it contains nothing that requires the creation of precedent. Whether published or not, it can be disposed of without the extra work needed to justify the creation and explain the application of new law.

Nevertheless, anyone who reads even a small number of unpublished opinions must conclude, given their brevity and informality, that considerable effort has been spared in their prepara- 
tion. Of course, one can then ask whether too much effort was spared. That is, does the quality of decision making suffer when the judges determine that an opinion need not be published and therefore that only a truncated opinion need be written? Before asking that question, however, the relation between publication and productivity must be examined.

2. Increased Productivity. If saving time and judicial effort in order to improve the courts' ability to handle a heavier caseload is the major goal of limited publication, the practice presumably should increase judicial productivity. ${ }^{59}$ It is easier to determine whether this is so if we limit ourselves to an investigation of the correlation between each circuit's use of limited publication and its relative judicial productivity. In other words, do the circuits that publish a comparatively small portion of their opinions have a comparatively good record of productivity? ${ }^{60}$ Before that question can be addressed, the concept of productivity must be defined.

Typically, judicial productivity is measured in terms of dispositions per authorized judgeship. ${ }^{61}$ That technique is unsatisfactory for two reasons. First, measuring productivity by authorized, but unfilled, judgeships does not produce very instructive comparisons. This is particularly true given our data, because authorized judgeships were increased from 97 to 132 during the study year. ${ }^{62} \mathrm{Be}$ cause none of the new judgeships was filled during the study year,

59 Of course, it is entirely possible that limited publication saves time but that the savings do not result in increased productivity. For example, instead of being spent in writing more decisions, the extra time could be invested in fashioning better-crafted opinions, or in more thought on the most difficult cases on the court's docket.

so Whether there is any relation between changes in a circuit's limitation of publication from year to year and increases or decreases in productivity is, of course, also relevant to determining limited publication's impact on productivity. That question is beyond the scope of our study because we have data from all the circuits but for only one fiscal year. In other words, we have investigated the horizontal question, but not the vertical one. Both methods of attack are pursued by Professor Daniel Hoffman of the University of Vermont in an unpublished article. D. Hoffman, Nonpublication of Federal Appellate Court Opinions 12 (1978) (on file with The University of Chicago Law Review). Professor Hoffman's instructive work differs from ours in two other respects as well: (1) In determining publication/ nonpublication rates, he used a population of "cases decided after argument or submissions." For reasons given in note $\mathbf{4 5}$ supra, our test population is the larger group of "cases decided with judicial action." (2) He used "dispositions per authorized judgeship" as a measure of productivity. For reasons given in text at notes 61-63 infra, we have used "corrected dispositions per judge" as the measure.

61 See, e.g., ANnual Report, supra note 35, at 45.

62 Id. at 44. 
using the traditional measure could skew the results significantly. Accordingly, we chose to evaluate productivity by using the number of active circuit judges instead of the number of authorized judgeships. A second difficulty with the standard measure of productivity is that the circuits use visiting and senior circuit judges to decide cases. ${ }^{63}$ That practice tends to skew productivity comparisons because the several circuits use visiting and senior judges to varying extents. Furthermore, if not compensated for, it would make total dispositions per active judgeship an inflated measure of productivity. We have corrected for these difficulties by subtracting from a circuit's total number of dispositions the share attributable to visiting and senior judges. Combining these two innovations, we measure productivity not by dispositions per authorized judgeship, but by dispositions per active circuit judge, corrected for the participation of senior and visiting judges: "corrected dispositions per judge," for short.

We now return to the central question: Is productivity positively correlated with nonpublication? The first column of Table 7 lists the circuits in order of productivity, from most corrected dispositions per judge to least. The second lists each circuit's corrected dispositions per judge. The third column gives the percentage of each circuit's total opinion production that was not published. Columns two and three show a positive correlation ${ }^{64}$ of 0.097 , indicating that there is scant tendency for circuits that publish less to produce more.

Our data thus provide no support for the hypothesis that limited publication enhances productivity ${ }^{65}$ It must be borne in mind, however, that limiting publication is only one of a host of variables that may affect productivity. The low productivity figures for the District of Columbia Circuit and the Second Circuit, for example, might well be attributable more to the great variety and complexity of the regulatory and commercial appeals that those courts must decide than to their publication habits. Other variables in-

is Id. at 50-51.

- A correlation is a report of the coincidence of two phenomena: $x$ and $y$. A positive correlation coefficient indicates that the value of the $x$ variable increases in proportion to the value of the $y$ variable. The correlation coefficients discussed in this article were computed with the Spearman Rho formula. Significance was tested with standard significance tables. See generally D. HarnetT \& J. Murphy, Introductory Statistical Analysis ch. 12 (2d ed. 1980).

es Professor Hoffman's study also found essentially no relationship between nonpublication and productivity. See D. Hoffman, supra note 60, at 11-26. 
clude the percentage of cases that are argued orally, ${ }^{66}$ the extent to which central staff is used to prepare opinions, and the geographical size of the circuit. ${ }^{87}$ Absent the ability to control or even quantify some of those variables, it is impossible to be certain of the effect of limited publication on productivity.

\section{TABLE 7}

Productivity and Publication

\begin{tabular}{lcc}
\hline Circuit & $\begin{array}{c}\text { Productivity } \\
\text { (Corrected Dispositions } \\
\text { per Judge) }\end{array}$ & $\begin{array}{c}\text { Unpublished Opinions } \\
(\%)\end{array}$ \\
\hline Fourth & 140.9 & 72.0 \\
Fifth & 138.6 & 41.4 \\
Sixth & 113.2 & 72.8 \\
Third & 108.4 & 81.9 \\
Seventh & 106.4 & 69.4 \\
Tenth & 101.4 & 68.9 \\
First & 99.2 & 40.7 \\
Ninth & 84.7 & 66.7 \\
Second & 76.0 & 61.1 \\
Eighth & 72.0 & 31.8 \\
D.C. & 61.6 & 72.2 \\
\hline
\end{tabular}

- Calculated from dispositions per circuit in Table 1 supra; participation by senior and visiting judges in ANNUAL REPORT, supra note 35, at 51; and number of active circuit judges in id. at 45.

b Because only the Second Circuit issues an appreciable number of oral opinions, its total dispositions from Table 1 were increased by 195 oral opinions. Calculated by the authors from data supplied by the Administrative Office of the United States Courts.

Bs Oral argument takes time, of course. In addition, it can be a bottleneck in the appellate process, because a court operating by traditional procedures cannot decide more cases than it can hear, and there are physical limitations on the number of cases it can hear. See P. Carrington, D. Mrador \& M. Rosenberg, supra note 3, at 19. Some courts have reported dramatic increases in output after establishing a system of curtailed oral argument. See Huth v. Southern Pac. Co., 417 F.2d 526 (5th Cir. 1969).

o7 Geography plays an important role in relative judicial productivity. Travel time is much greater in some circuits than in others. 


\section{B. Costs of Limited Publication}

The sections that follow examine the costs of limited publication. Two of those costs, suppression of precedent and diminished quality, accompany the benefits of swifter justice and savings of judicial effort. A third is the disparate impact of nonpublication, leading to the concern that some classes of litigants may be denied equal access to the courts. A final cost is systemic: the ultimate effect of limited publication is to transform the courts of appeals into certiorari courts in some instances.

1. Opinion Quality. Anyone who has read a large number of unpublished opinions must conclude that they are, as a group, far inferior in quality to the opinions found in the Federal Reporter. Although judgments about quality are largely subjective, some quantification of the differences between published and unpublished opinions is possible.

a. Length. Proponents of limited publication argue that time can be saved in the preparation of opinions that will not be published because they need not contain complete recitations of the facts or exhaustive discussions of the relevant legal principles. ${ }^{68}$ Hence, unpublished opinions should be considerably shorter than their published counterparts. ${ }^{60}$ This is confirmed by Tables 8 and 9. In every circuit, more than $55 \%$ of all unpublished opinions

os See Standards, supra note 17 , at 5 .

69 For obvious reasons, we were unable to perform evaluations on the total of nearly 8000 unpublished opinions produced during the Reporting Year, see text and notes at notes 42-45 supra. Accordingly, we chose a stratified sample of about $10 \%$ of the unpublished opinions for that portion of the study; the population of that sample is shown in Table A.

The sample was "stratified" in this sense: For each termination reported by the Administrative Office there is also a "Method of Disposition" reported. It can be (1) written opinion, (2) memorandum decision, (3) decided from the bench, (4) by court order without opinion, (5) by consent, or (6) other. See J.S. 34, box 12 . We stratified our sample by ensuring that the $10 \%$ of the total population included $10 \%$ of the cases decided by each of methods $1,2,4$, and 6 . We did so because we believed that there might be differences in quality based on method of disposition. We eliminated cases decided by methods 3 and 5 because they did not result in written case-dispositive orders resulting from judicial action, and hence could not be evaluated for quality or measured for length.

Our sample was not exactly $10 \%$. It varied from circuit to circuit for three reasons. First, the selections were made from a preliminary list of terminations-really docket numbers-prepared for us by the Administrative Office. Not every docket number represents an opinion; because some cases are consolidated for argument or opinion, several docket numbers may produce only one opinion. Hence, our original selection of $10 \%$ of docket numbers actually produced a sample of opinions that typically was closer to $12 \%$ of the total opinion population. Second, some of the opinions that we requested from the circuit court clerks were never sent. Third, some opinions originally listed as unpublished were later published. 
TABLE 8

LENGTH OF UNPUBLISHED OPINIONS

\begin{tabular}{lccccc}
\hline Circuit & $\begin{array}{c}\text { Below } \\
50 \text { Words } \\
(\%)\end{array}$ & $\begin{array}{c}50-99 \\
\text { Words } \\
(\%)\end{array}$ & $\begin{array}{c}100-299 \\
\text { Words } \\
(\%)\end{array}$ & $\begin{array}{c}300-499 \\
\text { Words } \\
(\%)\end{array}$ & $\begin{array}{c}500- \\
\text { Words } \\
(\%)\end{array}$ \\
\hline D.C. & 45.2 & 28.6 & 16.7 & 7.2 & 2.4 \\
First & 25.0 & 12.5 & 43.8 & 16.3 & 12.6 \\
Second & 45.4 & 20.4 & 23.4 & 7.8 & 3.2 \\
Third & 70.3 & 19.4 & 5.6 & 1.1 & 3.3 \\
Fourth & 42.9 & 15.6 & 21.5 & 9.6 & 10.8 \\
Fifth & 62.5 & 7.0 & 17.2 & 9.1 & 4.0 \\
Sixth & 6.0 & 22.6 & 61.9 & 8.4 & 1.2 \\
Seventh & 7.6 & 15.1 & 37.6 & 11.3 & 29.0 \\
Eighth & 15.8 & 21.0 & 31.6 & 10.6 & 21.1 \\
Ninth & 43.2 & 9.1 & 18.0 & 14.4 & 15.4 \\
Tenth & 13.0 & 22.3 & 20.4 & 11.2 & 33.4 \\
\hline
\end{tabular}

SouRcE: Stratified sample of the $\mathbf{7 7 2 0}$ unpublished opinions in Statistical Data, supra note 35, Table 5U. See Table A and note 69 supra.

NoTE: Figures for each circuit may not add up to $100 \%$ because of rounding.

(footnote 69 continued)

TABLE A

Sample Population

\begin{tabular}{lcc}
\hline Circuit & $\begin{array}{c}\text { Number of Unpublished } \\
\text { Opinions Analyzed }\end{array}$ & $\begin{array}{c}\text { Percentage of Total } \\
\text { Unpublished Dispositions }\end{array}$ \\
\hline D.C. & 61 & 12.1 \\
First & 17 & 11.6 \\
Second & 71 & 12.6 \\
Third & 123 & 12.4 \\
Fourth & 92 & 10.3 \\
Fifth & 101 & 10.3 \\
Sixth & 96 & 10.6 \\
Seventh & 92 & 12.5 \\
Eighth & 25 & 12.0 \\
Ninth & 146 & 11.8 \\
Tenth & 67 & 12.1 \\
\multicolumn{1}{c}{ Total } & 891 & \\
\hline
\end{tabular}


TABLE 9

Length of Published Opintons

\begin{tabular}{|c|c|c|c|c|c|}
\hline Circuit & $\begin{array}{c}\text { Below } \\
500 \text { Words } \\
(\%)\end{array}$ & $\begin{array}{c}500-999 \\
\text { Words } \\
(\%)\end{array}$ & $\begin{array}{c}\text { 1000-2999 } \\
\text { Words } \\
(\%)\end{array}$ & $\begin{array}{c}3000-4999 \\
\text { Words } \\
(\%)\end{array}$ & $\begin{array}{c}5000- \\
\text { Words } \\
(\%)\end{array}$ \\
\hline D.C. & 3.3 & 15.0 & 50.0 & 15.0 & 16.7 \\
\hline First & 2.7 & 26.0 & 52.1 & 15.1 & 4.2 \\
\hline Second & 11.1 & 12.4 & 51.7 & 18.0 & 6.7 \\
\hline Third & 4.2 & 14.9 & 50.0 & 17.6 & 13.6 \\
\hline Fourth & 23.4 & 29.9 & 33.8 & 9.1 & 3.9 \\
\hline Fifth & 18.8 & 24.2 & 43.6 & 7.3 & 6.0 \\
\hline Sixth & 30.1 & 16.4 & 39.8 & 11.0 & 2.7 \\
\hline Seventh & 4.5 & 11.4 & 73.9 & 4.5 & 5.7 \\
\hline Eighth & 16.8 & 29.8 & 48.1 & 4.6 & 0.8 \\
\hline Ninth & 18.5 & 24.6 & 44.7 & 10.6 & 1.8 \\
\hline Tenth & 3.2 & 28.1 & 61.0 & 7.9 & 0.0 \\
\hline
\end{tabular}

Source: Calculated from all opinions reported in volumes 595-600 of Federal Reporter (2d). Those six volumes contained substantial numbers of opinions from the survey year.

NoTE: Figures for each circuit may not add up to $100 \%$ because of rounding.

were shorter than 300 words. In six circuits, more than $40 \%$ of the unpublished opinions were shorter than 100 words. Published opinions, by contrast, are considerably longer. In nine of the eleven circuits more than $80 \%$ of all published opinions exceeded 500 words. In all eleven circuits, the largest group of published opinions was the group between 1000 and 3000 words. If we can safely assume that a relatively long opinion takes more time to prepare than a relatively short one, the claim that limited publication saves time is justified. ${ }^{70}$

b. Minimum standards. Not only are unpublished opinions shorter, they are so short that they raise serious questions concern-

70 If limited publication in fact saves time, but is not correlated with increased productivity, see text and notes at notes 64-65 supra, we are left with two alternate hypotheses: (1) the judges do not translate the time saved into extra dispositions, see note 59 supra; or (2) the other variables that affect productivity, see text and notes at notes 66-67 supra, conceal the effect of limited publication. 
ing the exercise of judicial responsibility. Does an opinion shorter than fifty words, often only a sentence or two, satisfy the court's institutional obligation?

To answer that question one must first consider the essential characteristics of the judicial opinion. At rock bottom, it must announce the result to the parties and explain to them the court's reasoning. ${ }^{71}$ It should also explain the result to a higher court and thus facilitate review. ${ }^{72} \mathrm{~A}$ final purpose is to "provide the stuff of the law":"73 rules of law, interpretations of statutes and constitutions, and declarations of public policy. Because the opinion publication plans clearly indicate that unpublished opinions are not designed to accomplish the "lawmaking" function, the present inquiry can be limited to whether unpublished opinions perform the first two functions satisfactorily.

A substantial consensus exists concerning the minimum standards that an opinion must meet if it is to perform those two functions adequately. One formulation states that even a memorandum decision must contain at least three elements: (1) the identity of the case decided; (2) the ultimate disposition; and (3) the reasons for the result. In addition, it is often desirable that the issues be stated explicity. ${ }^{74}$ How well these standards were met by our sample is shown in Table $10 .^{75}$

21 See StANDARDS, supra note 17 , at 2.

72 Id. at 2-3.

73 The phrase is from Leflar, Sources of Judge-Made Law, 24 OkLA. L. REv. 319 (1971).

74 P. Carrington, D. Mrador \& M. Rosenberg, supra note 3, at 34 . In addition, the American Bar Association recommends that

[e]very decision should be supported, at minimum, by a citation of the authority or statement of grounds upon which it is based. When the lower court decision was based on a written opinion that adequately expresses the appellate court's view of the law, the reviewing court should incorporate that opinion or such portions of it as are deemed pertinent, or, if it has been published, affirm on the basis of that opinon.

aBa Commission on Standards of Judiclal Administration, Standards Relating to ApPELLATE Courts 58 (1977). Karl Llewellyn said much the same thing:

The deciding is, in the main, done under felt pressure or even compulsion to follow up with a published "opinion" which tells any interested person what the cause is and why the decision-under the authorities-is right, and perhaps why it is wise.

This opinion is addressed also to the losing party and counsel in an effort to make them feel at least that they have had a fair break.

K. LlBwellyn, The Common Law Tradition 26 (1960). One survey of attorneys found that more than two-thirds of the respondents believed that "the due process clause of the Constitution should be held to require courts of appeals to write 'at least a brief statement of the reasons for their decisions.' " Hruska RBPORT, supra note 18, at 49 (quoting a survey undertaken by the Commission).

7s An opinion was listed as meeting minimum standards if it gave some indication of what the case was about and some statement of the reasons for the decision. Often a single 
TABLE 10

Satisfaction of Minimum Standards in Unpublished Opinions

\begin{tabular}{lccc}
\hline \hline Circuit & Reasoned Opinions (\%) & $\begin{array}{c}\text { Decided on the } \\
\text { Basis of the } \\
\text { Opinion Below (\%) }\end{array}$ & $\begin{array}{c}\text { No Discernible } \\
\text { Justification } \\
(\%)\end{array}$ \\
\hline D.C. & 34.1 & 4.9 & 61.0 \\
First & 68.8 & 6.3 & 25.0 \\
Second & 45.3 & 23.4 & 31.3 \\
Third & 13.6 & 1.1 & 85.2 \\
Fourth & 46.0 & 41.0 & 13.0 \\
Fifth & 36.0 & 5.0 & 59.0 \\
Sixth & 71.5 & 7.0 & 21.5 \\
Seventh & 77.5 & 1.3 & 21.3 \\
Eighth & 57.9 & 5.3 & 36.8 \\
Ninth & 65.8 & 0.0 & 34.2 \\
Tenth & 79.6 & 13.0 & 7.4 \\
\hline
\end{tabular}

Source: Compiled by the authors from the stratified sample in Table A supra. See note 75 supra.

Note: Figures for each circuit may not add up to $100 \%$ because of rounding.

Three circuits recorded double-digit percentages in the second category, cases decided on the basis of the opinion below. That sort of opinion provides a satisfactory explanation of the result to the parties, at least to the extent that the opinion below gives reasons for the result. By and large, the explanation is adequate only with respect to the parties, because most district court and administrative agency decisions are not published or readily accessible. Thus, the bar and the general public rarely will be able to oversee appellate decisions that culminate in a decision by reference. Another drawback to a decision by reference is that it may leave litigants

citation of precedent was considered satisfactory if the precedent was narrowly directed to the problem at hand; a citation to the general standard of review of an administrative or district court decision was not considered sufficient. Also considered insufficient to meet minimum standards were baldly conclusory opinions such as "appellant's contentions are frivolous and without merit," or "the conviction is supported by substantial evidence."

The reliability of the coding of opinions was established as follows: Each of the authors, using the coding method described above, applied it independently to all of the opinions in the sample. We agreed on $88 \%$ of the opinions for all circuits. 
with the feeling that the appellate court never really gave the case a fresh look. A short statement of the reasons for the decision in the appellate court's own words provides more evidence that serious thought has gone into the decision than does a blanket approval of the opinion below.

It is the third category, decisions with no discernible justification, that raises the issue of judicial irresponsibility most strikingly. ${ }^{78} \mathrm{~A}$ decision without articulated reasons might well be a decision without reasons or one with inadequate or impermissible reasons. That is not to suggest that judges will be deliberately arbitrary or decide cases without adequate grounds. The discipline of providing written reasons, however, often will show weaknesses or inconsistencies in the intended decision that may compel a change in the rationale or even in the ultimate result. Even if judges conscientiously reach correct results, an opinion that does not disclose its reasoning is unsatisfactory. Justice must not only be done, it must appear to be done. The authority of the federal judiciary rests upon the trust of the public and the bar. Courts that articulate no reasons for their decisions undermine that trust by creating the appearance of arbitrariness.

The decision without discernible justification takes various forms in the several circuits. Perhaps the most flagrant failure to provide reasons occurs in the Fifth Circuit. A substantial number of unpublished decisions by the court read simply "Affirmed. See Local Rule 21."7z The District of Columbia Circuit decides some cases "substantially upon the basis of the opinion below," a prac-

76 The practice of deciding cases with no articulated reasons has been roundly condemned by commentators, lawyers, and judges. See, e.g., Hearings, supra note 4, at 451-52 (testimony of Edward Hickey, President, Bar Association of the Seventh Circuit); id. at 555 (testimony of Willard Lassers on behalf of the American Civil Liberties Union and the Chicago Lawyers Committee for Civil Rights Under Law); id. at 826 (testimony of Judge Doyle of the Tenth Circuit); id. at 933 (testimony of Professor Haworth); id. at 951 (testimony of Professor Carrington); id. at 1107 (testimony of Judge Skelton of the Court of Claims); Note, supra note 4, at 134-35.

77 5TH CrR. R. 21 authorizes such a truncated order when the court finds

(1) that a judgment of the District Court is based on findings of fact which are not clearly erroneous, (2) that the evidence in support of a jury verdict is not insufficient, (3) that the order of an administrative agency is supported by substantial evidence on the record as a whole; and the Court also determines that no error of law appears and an opinion would have no precedential value, the judgment or order may be affirmed or enforced without opinion.

Affirming under this rule thus is not a decision by reference, but simply a declaration that the decision below was not wrong. Furthermore, the failure even to refer to the opinion below adds another layer of obscurity to the decisional process. 
tice even less satisfactory than the usual decision by reference because it does not indicate which portions of the opinion below are accepted and which are rejected. The Third Circuit produces a large number of opinions that simply list the appellant's contentions and then order that the judgment be affirmed. That practice, although perhaps more instructive than a one-word affirmance, gives no indication why each contention was rejected, nor does it give any indication that the court gave any serious thought to the appellant's brief. Several circuits employ what might best be described as form orders or judgments. ${ }^{78}$ These orders recite that "after due consideration" or "upon a review of the record and the briefs of the parties," the "appeal is dismissed as frivolous" or "appellant's contentions are without merit."

\section{Quality and Productivity}

The percentage of below-standard unpublished opinions varies greatly among the circuits, from a high of $85 \%$ in the Third Circuit to a low of $7 \%$ in the Tenth Circuit. It might be expected that those circuits with the highest percentage of below-standard unpublished opinions are the most overworked. That is, short opinions may be necessary in order to permit those courts to keep up to date. The data in Table 11, however, suggest that such is not the case.

The first column lists the circuits in order of productivity. ${ }^{70}$ The second displays the percentage of below-standard unpublished opinions. ${ }^{80}$ The data show no positive correlation..$^{81}$ In other words,

78 The Second, Third, Fifth, and Sixth Circuits make some use of the formula type order.

78 See Table 7 supra.

so See Table 10 supra.

o1 In fact the correlation was negative: -.140. Another way to test the hypothesis that very short opinions are necessary to high productivity is to correlate productivity with the percentage of minimum standard opinions produced. That would remedy a possible defect in Table 11. The Second Circuit and the Fourth Circuit show relatively low percentages both of below-standard opinions and of minimum standard opinions. See Table 10 supra. This is the result of high percentages of decisions by reference. It may be that the lack of correlation in Table 11 is caused by the fact that the most productive circuit, the Fourth, relies to a large extent on decisions by reference. This difficulty can be eliminated by correlating the percentage of minimum standard opinions with productivity. If the hypothesis that short opinions are necessary to productivity is correct, we should find a strong negative correlation. Once again the hypothesis is not proved. As shown in Table B, there is a negative correlation, but it is quite weak: -.047 . 
TABLE 11

Productivity and Below-Standard UnPublished Opinions

\begin{tabular}{lcc}
\hline \hline Circuit & $\begin{array}{c}\text { Productivity (Corrected } \\
\text { Dispositions per Judge) }\end{array}$ & $\begin{array}{c}\text { Percentage of } \\
\text { Unpublished Opinions } \\
\text { That Are Below } \\
\text { Standard }\end{array}$ \\
\hline Fourth & & 13.0 \\
Fifth & 140.9 & 59.0 \\
Sixth & 138.6 & 21.5 \\
Third & 113.2 & 85.2 \\
Seventh & 108.4 & 21.3 \\
Tenth & 106.4 & 7.4 \\
First & 101.4 & 25.0 \\
Ninth & 99.2 & 34.2 \\
Second & 84.7 & 31.3 \\
Eighth & 76.0 & 36.8 \\
D.C. & 72.0 & 61.0 \\
\hline
\end{tabular}

Source: Tables 7,10 supra.

(footnote 81 continued)

TABLE B

Productivity and Minimum Standard Opinions

\begin{tabular}{lcc}
\hline Circuit & $\begin{array}{c}\text { Productivity (Corrected } \\
\text { Dispositions per Judge) }\end{array}$ & $\begin{array}{c}\text { Percentage of Unpublished } \\
\text { Opinions That Meet } \\
\text { Minimum Standards }\end{array}$ \\
\hline Fourth & 140.9 & 46.0 \\
Fifth & 138.6 & 36.0 \\
Sixth & 113.2 & 71.5 \\
Third & 108.4 & 13.6 \\
Seventh & 106.4 & 77.5 \\
Tenth & 101.4 & 79.6 \\
First & 99.2 & 68.8 \\
Ninth & 84.7 & 65.8 \\
Second & 76.0 & 45.3 \\
Eighth & 72.0 & 57.9 \\
D.C. & 61.6 & 34.1 \\
\hline
\end{tabular}

SOuRcE: Tables 7,10 supra. 
the most productive circuits were not the ones that produced the most substandard opinions. ${ }^{82}$

The use by the circuits of excessively brief opinions with no discernible justification cannot be supported. The cost of this practice is high; use of such opinions subverts many of the goals of appellate justice. The benefit of the practice is doubtful at best; the data reveal no correlation between productivity and the use of cryptically short opinions.

2. Suppressed Precedent. The lower quality of unpublished opinions may be the most important of the costs of limited publication, but it has not been the most controversial. That role has been played by the question of suppressed precedent. ${ }^{83} \mathrm{By}$ suppressed precedent, we mean a case that ought to have been pub-

ox Nor did the most productive circuits produce the most very short unpublished opinions, as is shown in the table below:

TABLE C

Productivity and Very Short Opinions

\begin{tabular}{lcc}
\hline \hline Circuit & $\begin{array}{c}\text { Productivity (Corrected } \\
\text { Dispositions per Judge) }\end{array}$ & $\begin{array}{c}\text { Percentage of Unpublished } \\
\text { Opinions That Are Shorter } \\
\text { than 50 Words }\end{array}$ \\
\hline Fourth & 140.9 & 42.9 \\
Fifth & 138.6 & 62.5 \\
Sixth & 113.2 & 6.0 \\
Third & 108.4 & 70.3 \\
Seventh & 106.4 & 7.6 \\
Tenth & 101.4 & 13.0 \\
First & 99.2 & 25.0 \\
Ninth & 84.7 & 43.2 \\
Second & 76.0 & 45.4 \\
Eighth & 72.0 & 15.8 \\
D.C. & 61.6 & 45.2 \\
\hline
\end{tabular}

SOURCE: Tables 8,10 supra.

Again the correlation is weak: .151 .

As might be expected, there is a high positive correlation between the percentage of below-standard opinions and the percentage of opinions shorter than 50 words: .758 , as is shown in Table $D$.

For an explanation of how correlations are calculated and their significance, see note 64 supra. 
lished but was not. ${ }^{84}$ Our examination has convinced us, however, that suppressed precedent is not an insuperable problem of limited publication. The discussion that follows examines the problem of suppressed precedent generally and in the specific contexts of reversals and separate opinions.

a. Generally. Our sample of unpublished opinions ${ }^{85}$ revealed a number of instances of suppressed precedent. It is difficult to estimate how widespread the phenomenon was. An opinion that relies on no authority, for example, could be said to be breaking new ground, or it may only be that the issue is so well settled that citation would be superfluous. ${ }^{86}$ To determine with any certainty whether an opinion makes new law requires a familiarity with the substantive law of the circuits that is far beyond the scope of this study. The problem of identifying suppressed precedent becomes even more acute when one considers that discussions of "settled" law in novel settings may in fact shift the moorings of the "settled" principles. Detection of such nuances is difficult. Nevertheless, some conclusions can be drawn with reasonable assurance.

(footnote 82 continued)

TABLE D

Brlow-Standard Opinions and Very Short Opinions

\begin{tabular}{lcc}
\hline Circuit & $\begin{array}{c}\text { Percentage of Unpublished } \\
\text { Opinions That Are Below } \\
\text { Standard }\end{array}$ & $\begin{array}{c}\text { Percentage of Unpublished } \\
\text { Opinions That Are } \\
\text { Shorter than 50 Words }\end{array}$ \\
\hline Third & 85.2 & 70.3 \\
D.C. & 61.0 & 45.2 \\
Fifth & 59.0 & 62.5 \\
Eighth & 36.8 & 15.8 \\
Ninth & 34.2 & 43.2 \\
Second & 31.3 & 45.4 \\
First & 25.0 & 25.0 \\
Seventh & 21.3 & 7.6 \\
Sixth & 21.5 & 6.0 \\
Fourth & 13.0 & 42.9 \\
Tenth & 7.4 & 13.0 \\
\hline
\end{tabular}

SoUrce: Tables 8, 10 supra.

ss See, e.g., Gardner, supra note 4; Comment, supra note 4.

"Our use of the word "suppressed" is not intended to connote in any way that these cases are being deliberately concealed.

s3 See note 69 supra for a description of the sample.

se $\mathrm{Or}$, to put the last point differently, the case may have provided materials for changing the law but the court refused to play the role of artisan. 
We discovered no widespread "hiding" of law-declaring opinions-that is, opinions that clearly broke new ground on important issues. There were, to be sure, some exceptions. ${ }^{87}$ One example is Trible v. Brown. ${ }^{88}$ There a Congressman sought to compel the Department of Defense to file a report on two shipyard programs. The litigation raised interesting questions of standing, ${ }^{80}$ justiciability, and remedy. In spite of its obvious importance, the Fourth Circuit did not publish the opinion..$^{30}$

Cases like Trible were unusual..$^{81}$ More frequent examples of suppressed precedent involved questions of state law, often in relation to federal statutory or constitutional law. Such opinions certainly should be published if they resolve novel issues. In DeBona v. Vizas, ${ }^{92}$ for example, the Tenth Circuit decided that two policemen had not been denied due process when their positions were terminated. The decision turned on whether a Colorado statute created a protected property interest, ${ }^{\text {93 }}$ and apparently it was a case of first impression. The importance of the court's resolution of the problem was increased because the state statute involved had not been construed since 1900. In those circumstances, the resolution of the due process claim deserved general circulation. ${ }^{94}$

sz Eyes more attuned than ours to the subtleties of criminal procedure might have spotted more "clear" precedent. But the point is there were few cases that grabbed the attention of the alert general reader. Others who have done more limited studies, particularly in state appellate courts, report reading unpublished opinions that begin, in effect, "This is a case of first impression in our state." See, e.g., Kanner, supra note 3, at 391; Newbern \& Wilson, supra note 3 , at 48-56. We have few such stories to tell.

${ }^{83}$ No. 79-1228 (4th Cir. May 2, 1979).

89 Plaintiff argued that he needed the reports in order to exercise his oversight role effectively. Compare Kennedy v. Sampson, 511 F.2d 430 (D.C. Cir. 1974) (alleged interference with exercise of legislative power gives Congressmen standing) with Harrison v. Bush, 553 F.2d 190 (D.C. Cir. 1977) (no standing where Congressman's interest in enforcement of statute is no greater than that of an ordinary citizen).

0 It may have been held back from publication because it originally was an oral opinion. That does not detract, however, from its status as a law-declaring opinion. It was a judicial expression on important legal issues.

91 Often an opinion that at first appeared clearly to warrant publication seemed less important on closer examination. AT\&T v. Grady, No. 78-2316 (7th Cir. Dec. 14, 1978), provides an example. The issue there, whether a nonparty, the federal government, should be granted a modification of a protective order so it could gain access to discovered documents, was said by the court to have been resolved in different ways by trial courts and to be "a case of appellate first impression." Id., slip op. at 5. The opinion turned on the particular facts of the case at bar, however, considerably reducing its value as precedent. Although the discussion probably was significant enough to warrant publication, it was not as important as the court's statements might have led the reader to believe.

${ }_{92}$ No. 77-1299 (10th Cir. Dec. 18, 1978).

${ }^{93}$ See Bishop v. Wood, 426 U.S. 341 (1976).

- See also United States ex rel. Aurora Pump Co. v. Ranger Constr. Co., No. 77-1991 
Suppressed precedent can also be found in cases resolving novel questions of state law. The federal courts' reluctance to publish opinions on state law questions is understandable. Still, such opinions can provide useful guidance in areas where no state precedent exists. An example is Grant Square Bank \& Trust Co. $v$. Magnavox $\mathrm{Co}^{9{ }^{95}}$ a contract case where the court relied in part on promissory estoppel, but cited no state cases accepting that doctrine. ${ }^{98}$

Although nonpublication of law-declaring opinions does occur, our review of the opinions in our sample has convinced us that it is not a major problem with limited publication. The handful of examples we discovered constituted less than $1 \%$ of the nearly 900 opinions in our sample.97

Perhaps more common than unpublished law-declaring opinions were cases that were of public interest because they revealed defects in the law or its administration. ${ }^{98}$ Those opinions deserved wider circulation in order to reveal these flaws to a large audience, which is the best way to ensure their correction.

The Longshoremen's and Harbor Worker's Compensation Act, ${ }^{92}$ for example, was designed to provide employees with "swift compensation for work-related injuries, regardless of fault, and the cost of resolving disputes relating to such compensation would be kept to a minimum."100 Unfortunately, the plan does not always

(4th Cir. Sept. 6, 1978). The question there was whether timely notice was given under the Miller Act, 40 U.S.C. $\$ 270$ (b) (1976). The court's sensible construction of the statute was not supported by any citation. If Aurora Pump was a case of first impression, it should have been published.

Another example is Hale v. Walker, No. 78-1443 (10th Cir: Mar. 12, 1979) (no cause of action under 42 U.S.C. $\$ 1983$ (1976) for failure to expunge an arrest record; court cited no authority for its holding).

ss No. 77-1070 (10th Cir. Sept. 6, 1978).

* See also Gard v. United States, 594 F.2d 1230 (9th Cir. 1979), which applied the Nevada sightseer statute, NEv. RBV. STAT. $\$ 41.510$ (1967), in a case of first impression. Although originally unpublished, the case subsequently was ordered published, which indicated a commendable, if belated, awareness of the importance of cases of this type.

"7 See note 69 supra for a description of the sample.

* Several circuits provide expressly for publication of such opinions. The Fourth, Seventh, and Ninth Circuits, for instance, call for publication of an opinion that "criticizes existing law." 4TH CIR. R. 18(a)(iii); 7TH CIR. R. 35(c)(iii); 9TH CIR. R. 21 (b)(3). The District of Columbia, Fourth, Seventh, Eighth, and Ninth Circuits require publication of an opinion that "involves an issue of continuing public interest." District of Columbin Circuit Plan para. e; 4TH CIR. R. 18(a)(ii); 7TH CIR. R. 35(c)(ii); 8TH CIR. R. app. I 4(d); 9TH CIR. R. $21(\mathrm{~b})(4)$.

• 33 U.S.C. $\$ 901$ (1976).

100 Universal Terminal \& Stevedoring Corp. v. Norat, No. 78-1029, slip op. at 2 (3d Cir. Feb. 8, 1979). 
work that well, as the Third Circuit noted in one unpublished opinion that described in detail one longshoreman's continuing efforts-eight years after an accident-to obtain relief. ${ }^{101}$ The court reluctantly remanded to the agency. Publication of this story might have helped bring about change; certainly its suppression will not help achieve that goal.

In similar fashion, American Bankers Association v. Connell ${ }^{102}$ described problems associated with fund transfers by financial institutions. The court noted that it was "convinced that the methods of transfer authorized by the agency regulations have outpaced the methods and technology of fund transfer authorized by the existing statute."103 Such a statement from an influential court could have stimulated reform. Instead, it was not published.

Courts are uniquely situated to spot problems in the application of a statute or the workings of an agency. Their comments on the subject can enlighten those in a position to act. There is no reason not to publish those expressions.

A closely related type of case contains commentary by judges on the workings of their own courts. The judiciary has an institutional obligation to set its own house in order. Judges should not be permitted to sweep their peers' shortcomings under the rug by nonpublication. Those who have the duty to supervise the judiciary should see the whole picture, warts and all. Further, public exposure of the faults of judges may have a salutary effect on performance. Reversal in public is a far different matter than what amounts to a private reprimand in an unpublished opinion.

Several unpublished opinions in our sample involved mistakes made by district judges that led to reversal or at least admonition by the circuit court. We believe that those cases should have been made public. Elementary mistakes in routine cases deserve public attention; judicial accountability cannot exist if no one but the circuit court is aware of judicial errors. When an appellate court must remind a district judge of the necessity of subject matter jurisdiction, ${ }^{104}$ for instance, something is seriously amiss. The same can be said when a court must reinstate a complaint because it was "dismissed pursuant to a procedure this court reviewed and found defi-

101 Id.

102 No. 78-1337 (D.C. Cir. Apr. 20, 1979).

10 Id., slip op. at 2.

104 See Bergeron v. Exxon Corp., No. 78-2318 (5th Cir. Apr. 19, 1979). 
cient [the preceding year]."105 Pressure through publicity should be brought to bear on such trial judges.

The nonpublication of opinions that reveal problems transcending mere mistake is even more objectionable. Such cases give rise to a strong suspicion that the court does not care to wash its dirty linen in public. A prime example is United States $v$. Ritter ${ }^{108}$ where the full Tenth Circuit vacated an order issued by Chief Judge Willis Ritter of the District of Utah. The order in question prohibited the judge's "court reporter from carrying out the duties imposed upon him by law." 107 The decision came at a time when Congress was considering a proposal to create a procedure, short of impeachment, to hold federal judges accountable; the problems of Chief Judge Ritter figured in the debate. ${ }^{108}$ The scope of the problems he had created clearly should have been revealed to a directly interested Congress and legal community.

Suppression of law-declaring opinions does not appear to be a major problem of limited publication. That is not surprising, given our findings concerning the quality of decision making in unpublished opinions. The concern should not be the suppression of precedent; instead, it should be whether the judges examined the cases closely enough to see if precedent should be made. ${ }^{109}$ The major danger we see is that the early decision not to publish an opinion means that not enough care will go into its preparation to stimulate the thought necessary to an adequate consideration of whether precedent should be created. That basic issue of judicial responsibility should be the concern of the judiciary and of the public.

More troublesome than the suppression of law-declaring opinions was the nonpublication of decisions suggesting that statutes, agencies, or the courts themselves are not performing up to par. Appellate courts should recognize that they have a unique vantage point from which to observe the workings of our society. Observations from that point are of interest to all.

105 McGruder v. Jeansonne, No. 78-3236 (5th Cir. Mar. 27, 1979). See also Moorer v. Griffin, No. 77-3580 (6th Cir. Oct. 12, 1978), where the District Court dismissed the complaint for failure to prosecute. The Sixth Circuit reversed because the plaintiff was in jail and the court had not directed that his body be produced for argument.

106 No. 77-1491 (10th Cir. Aug. 11, 1978).

102 Id., slip op. at 1.

108 S. REP. No. 1035, 95th Cong., 2d Sess. 4 (1978).

100 Some observers have worried that the Seventh Circuit, for example, has suppressed too many law-declaring opinions. See Hearings, supra note 4, at 556 (statement of Willard 
b. Separate opinions. Nonpublication presents a special problem when an unpublished opinion contains a concurring or dissenting opinion. Two major factors argue for publication in cases that generate separate opinions. First are the stated premises of limited publication, which is a treatment supposedly reserved for cases that do not implicate the lawmaking function of the court ${ }^{110}$-routine, uncontroversial cases. Cases that contain dissents or concurrences are, by definition, controversial; the court disagrees either about the result to be reached or about the method used to reach it. Accordingly, few decisions with separate opinions should go unpublished.

Second is the role played by the separate opinion in our judicial system. ${ }^{111}$ Separate opinions serve to restrain judical advocacy. Like all advocates, the judicial advocate can lose sight of the other side. The separate opinion restricts the judicial advocate because it assures him of a public airing of a contrary view of the same facts and law. ${ }^{112}$ The separate opinion also performs an important corrective function, for it criticizes the result and reasoning of the majority, appealing for correction by a higher court, a future court, or a legislature. It is "an appeal to the brooding spirit of the law, to the intelligence of a later day."11s

In order to perform these functions adequately, the separate opinion must be published. ${ }^{114}$ The judicial advocate will not be re-

Lassers). See also Comment, supra note 4. Our review convinced us that, instead, the Seventh Circuit has a commendable record of explaining its decisions. Some incidental suppression of precedent in that process seems a legitimate price to pay; it is preferable to a court's avoiding any risk of suppressing a law-declaring opinion by not providing any reasons for its unpublished decisions.

110 See STANDaRDS, supra note 17, at 1-2.

11 See generally W. REYNoLDs, supra note 6, at 23-27; Fuld, The Voices of Dissent, 62 Colum. L. REv. 923, 926-28 (1962); Stephens, The Function of Concurring and Dissenting Opinions in Courts of Last Resort, 5 U. FiA. L. Rev. 394 (1952).

${ }^{112}$ Stephens, supra note 111, at 403-04.

${ }^{113}$ C. Hughes, The Supreme Court of the UntTed States 68 (1928) (describing dissent in courts of last resort).

114 One important function of the separate opinion can be accomplished even if the opinion goes unpublished. Judge Fuld wrote that "the dissent is an assurance that the case was fully considered and thoroughly argued by the bench as a whole and was not merely adopted as written by one member." Fuld, supra note 111, at 927. An unpublished dissent or concurrence may still provide that assurance, at least to the parties and the lower court. It can, however, fail even that limited function. Consider National Treasury Employees Union v. United States Dep't of the Treasury, No. 78-1282 (D.C. Cir. May 15, 1979). The opinion reads as follows:

This cause came on to be heard on the record on appeal from the United States District Court for the District of Columbia, and was argued by counsel. While the issues 
strained by a dissent that never sees the light of day. An appeal for correction is largely useless if the appeal is not disseminated to those with the power to correct the majority's errors. ${ }^{115}$

Thus, both the criteria for cases that should remain unpublished and the functions of the separate opinions lead to the conclusion that few cases that generate separate opinions should go unpublished. The data from the survey year, as illustrated by Table 12, confirm that hypothesis. The frequency of separate opinions among the circuits' published opinions ranged between $2.8 \%$ and $21.1 \%$; in the unpublished opinions it ranged from a low of $0 \%$ to a high of $1.5 \%$. Taking all the circuits together, the average frequency of separate opinions in published opinions was $12.4 \%$, in unpublished opinions $0.5 \%$. Divided courts thus were more than 20 times more common in cases decided by published opinions than in those decided by unpublished opinions.

The important question, however, is whether any case that is sufficiently controversial to generate a separate opinion should go unpublished. Of the separate opinions in our sample, two had little to offer to the legal literature. ${ }^{116}$ One was too short to evaluate. ${ }^{117}$ The other two, however, should have been published.

presented occasion no need for an opinion, they have been accorded full consideration by the Court. See Local Rule 13(c).

On consideration of the foregoing, it is ordered and adjudged by this Court that the judgment of the District Court appealed from in this case is hereby affirmed.

To that informative recitation, which consists of a printed form with the words "judgment" and "affirmed" written in, is added the equally terse "Chief Judge Wright dissents." That sort of opinion complete with dissent not only fails to accomplish the restraining and correcting functions but also fails to assure "that the case was fully considered by the bench as a whole." It takes 83 words to say to the appellant "you lost 2-1."

118 Another reason to publish opinions with dissents is to ensure that the majority cannot suppress the views of a dissenting judge. We are not aware of any federal cases where that has occurred. The problem has arisen in some state cases, however. In People v. Para, No. CRA 15889 (Cal. Ct. App. Aug. 1979), Judge Jefferson wrote in dissent:

Initially, it appeared that the majority felt the same as I do regarding the fact that the majority opinion merited publication in the Official Reports. When circulated to me, the majority opinion was approved by the two justices making up the majority and was marked for publication in the Official Reports. It was only after I had circulated my dissenting opinion to the two justices who make up the majority that they decided to reverse their original position regarding publication in the Official Reports. I do not think this reversal of position is justified.

Id. at 34 .

116 In Costello Publishing Co. v. Rotelle, No. $79-1019$ (D.C. Cir. May 17, 1979), the district court dismissed the counterclaim under FaD. R. CIv. P. 19(b) because the action "in equity and good conscience" should not proceed among the present parties due to the 
TABLE 12

Separate Opinions

\begin{tabular}{|c|c|c|c|c|c|}
\hline \multicolumn{6}{|c|}{ Published } \\
\hline Circuit & $\begin{array}{c}\text { Total } \\
\text { Opinions }\end{array}$ & Dissenting & Concurring & $\begin{array}{l}\text { Concurring } \\
\text { \& Dissenting }\end{array}$ & $\begin{array}{c}\text { Separate } \\
\text { Opinions } \\
(\%)\end{array}$ \\
\hline D.C. & 194 & 21 & 12 & 8 & 21.1 \\
\hline First & 214 & 2 & 4 & 0 & 2.8 \\
\hline Second & 359 & 28 & 34 & 9 & 19.8 \\
\hline Third & 219 & 26 & 10 & 4 & 18.3 \\
\hline Fourth & 346 & 53 & 6 & 8 & 19.4 \\
\hline Fifth & 1385 & 62 & 55 & 9 & 9.1 \\
\hline Sixth & 340 & 13 & 5 & 6 & 7.1 \\
\hline Seventh & 325 & 30 & 9 & 8 & 14.5 \\
\hline Eighth & 448 & 21 & 10 & 2 & 7.4 \\
\hline Ninth & 618 & 14 & 2 & 9 & 4.0 \\
\hline Tenth & 251 & 16 & 12 & 4 & 12.7 \\
\hline Average & & & & & 12.4 \\
\hline \multicolumn{6}{|c|}{ UNPUBLISHED } \\
\hline Circuit & $\begin{array}{c}\text { Total } \\
\text { Opinions }\end{array}$ & Dissenting & Concurring & $\begin{array}{l}\text { Concurring } \\
\text { \& Dissenting }\end{array}$ & $\begin{array}{c}\text { Separate } \\
\text { Opinions } \\
(\%)\end{array}$ \\
\hline D.C. & 505 & 2 & 1 & 1 & 0.8 \\
\hline First & 147 & 0 & 0 & 0 & 0.0 \\
\hline Second & 563 & 1 & 0 & 0 & 0.2 \\
\hline Third & 991 & 4 & 1 & 0 & 0.5 \\
\hline Fourth & 890 & 1 & 1 & 0 & 0.2 \\
\hline Fifth & 978 & 0 & 1 & 0 & 0.1 \\
\hline Sixth & 908 & 2 & 2 & 0 & 0.4 \\
\hline Seventh & 736 & 4 & 6 & 1 & 1.5 \\
\hline Eighth & 209 & 1 & 0 & 0 & 0.5 \\
\hline Ninth & 1238 & 2 & 0 & 1 & 0.2 \\
\hline Tenth & 555 & 3 & 2 & 1 & 1.1 \\
\hline Average & & & & & 0.5 \\
\hline
\end{tabular}

Source: Statistical Data, supra note 35, Tables IP, 2P, 3U, $5 U$. 
American Textile Manufacturers Institute, Inc. v. Bingham (ATMI) ${ }^{118}$ surely deserved public dissemination. It involved an issue that, although arcane, has broad implications. The Occupational Safety and Health Act ${ }^{119}$ provides for judicial review by the circuit courts of safety and health standards. ${ }^{120}$ Often petitions for review will be filed in more than one circuit; the case is then heard in the circuit in which the first petition was filed. ${ }^{131}$ A petition filed before the issuance of the regulation is considered premature. ${ }^{122}$ In ATMI, the challenged regulation was delivered to the Federal Register at 9:00 A.M. and made available to the public at 11:53 A.M. Several labor organizations filed petitions for review in the District of Columbia Circuit at 8:45 A.M. and 11:55 A.M. ATMI filed at 8:45:01, 11:00:00 A.M., and exactly noon in the Fourth Circuit. ${ }^{123}$ Clearly, the venue for the appeal will be determined by whether 9:00 A.M. or 11:53 A.M. was the time the regulation was issued. The dissent, relying on a provision in the statutory authorization for the Federal Register, ${ }^{124}$ thought that ATMI had filed first. The majority, relying on an interpretive regulation issued by OSHA, ${ }^{125}$ held that the unions had filed first.

court's lack of jurisdiction over a foreign firm that possessed evidence essential to determining the merits. The court of appeals reversed on the theory that the dismissal was premature because Frs. R. Crv. P. 28(b) permits discovery in foreign countries. The correct time for dismissal, said the court, would be after such efforts at discovery had failed. Judge MacKinnon concurred; his opinion essentially is a message to the district judge indicating those factors mentioned in Rule 19(b) that Judge MacKinnon considered especially important.

United States v. Vera, No. 77-5363, (6th Cir. July 10, 1978), is another case in which the separate opinion is of only marginal import. The issue that generated Judge Merritt's concurrence was defendant's motion to transfer the case from Kentucky to Texas. Defendant was engaged in a scheme to distribute marijuana in Kentucky when his airplane crashed and was captured in Texas. The District court denied the motion to transfer and was affirmed. Judge Merritt concurred even though he would have felt "more comfortable" had the case been transferred. Id. at 2. The relevant standard is "for the convenience of parties and witnesses, and in the interest of justice." Fro. R. CRMM. P. 21(b). Vera is an unremarkable application of that standard.

11 See note 114 supra.

11 No. 78-1378 (4th Cir. Oct. 3, 1978).

11029 U.S.C. \$§ 651-678 (1976).

${ }^{120}$ Id. $\S 655(\mathrm{f})$.

12123 U.S.C. \& 2112(a) (1976).

${ }^{122}$ See Industrial Union Dep't v. Bingham, 570 F.2d 965, 968-69 (D.C. Cir. 1977).

123 The statement of the facts is taken from Respondent Secretary's Motion to Dismiss and to Transfer, ATMI v. Bingham, No. 78-1378 (4th Cir. July 11, 1978) (on file with The University of Chicago Law Review).

124 44 U.S.C. $\$ 1503$ (1976) (documents to be publicly available immediately after filing).

12829 C.F.R. \& 1911.18(d) (1980). 
The majority and dissent, then, disagreed upon a rule of law-a rule that could be settled one way or the other without shaking the legal firmament, but a rule that should be settled. Publication would have advanced the ultimate national resolution of this issue.

Another case that should have been published is Burrison $v$. New York City Transit Authority, ${ }^{126}$ which revealed a longstanding disagreement within a circuit. The issue was the res judicata effect of findings in a state criminal or quasi-criminal proceeding upon a subsequent federal civil rights litigation. In Burrison and other cases, Judge Oakes has consistently favored a much narrower scope for the doctrine of res judicata than has the majority. ${ }^{127}$ The issue has also caused a split between the Second Circuit and the Sixth Circuit, ${ }^{128}$ and it has been the subject of scholarly dispute. ${ }^{129}$ It seems odd that, faced with such a controversial question, the court should not treat the issues in comprehensive fashion ${ }^{130}$ and publish that treatment. Nonpublication surely is inappropriate for cases concerning such a persistently troublesome issue.

It might be argued that the controversial issues in Burrison had already been treated by the court in published opinions. Additional publication of dissenting views arguably is unnecessary, as well as damaging to the collegiality of the court. But frequent public airing of disagreement is the only way to settle such stubborn disputes, and it may be the only way to attract sufficient attention from the Supreme Court to provoke a grant of certiorari.

After considering the principles underlying limited publication and separate opinions, it seems clear that the circuits should adopt

${ }^{128}$ No. 78-7536 (2d Cir. Mar. 29, 1979).

${ }_{127}$ See Turco v. Monroe County Bar Ass'n, 554 F.2d 515 (2d Cir.) (in which Judge Oakes disagreed with the majority, but concurred in the result because he felt he was bound by the "law of the circuit," id. at 522), cert. denied, 434 U.S. 834 (1977); Thistlethwaite v. New York, 497 F.2d 339, 343 (2d Cir.) (Oakes, J., dissenting), cert. denied, 419 U.S. 1093 (1974); Tank v. Appellate Div., 487 F.2d 138, 143 (2d Cir. 1973) (Oakes, J., dissenting), cert. denied, 416 U.S. 906 (1974).

${ }^{128}$ See Getty v. Reed, 547 F.2d 971 (6th Cir. 1977).

129 See H. Friendly, Federal Jurisdiction: A Gengral View 101-02 \& n.113 (1973); Theis, Res Judicata in Civil Rights Act Cases: An Introduction to the Problem, $70 \mathrm{Nw}$. U. L. REv. 859 (1976).

1so The problem here is really more serious than nonpublication; the court's opinion contains about 120 words. The facts are omitted entirely and the entire legal discussion consists of three case citations. Judge Oakes joined the majority opinion, limiting his disagreement to the statement that he adhered to his position in Turco. This may well be an instance where nonpublication led to a case receiving less attention than it merited. 
the rule that all cases containing separate opinions should be published. Such a rule would cost little. In the survey year, only thirtyeight separate opinions went unpublished- $0.5 \%$ of the total unpublished product of the circuit courts. ${ }^{131}$ In return for the minimal cost of publishing these few decisions, the courts would be able to ensure publication of a group of opinions that should be available to guide litigants and planners, provoke critical commentary, and perhaps interest the Supreme Court in resolving a controversial question.

c. Reversals. About one in every seven unpublished opinions did something other than affirm the opinion below (see Table 13).

TABLE 13

Frequency of Nonafpirmance

\begin{tabular}{lccc}
\hline \hline Circuit & $\begin{array}{c}\text { In Published } \\
\text { Opinions (\%) }\end{array}$ & $\begin{array}{c}\text { In Unpublished } \\
\text { Opinions (\%) }\end{array}$ & $\begin{array}{c}\text { Number of } \\
\text { Nonaffirming } \\
\text { Unpublished } \\
\text { Opinions }\end{array}$ \\
\hline D.C. & 44 & 14 & 67 \\
First & 32 & 12 & 17 \\
Second & 37 & 9 & 51 \\
Third & 50 & 8 & 77 \\
Fourth & 43 & 14 & 121 \\
Fifth & 36 & 11 & 109 \\
Sixth & 41 & 12 & 111 \\
Seventh & 38 & 16 & 118 \\
Eighth & 28 & 17 & 35 \\
Ninth & 28 & 19 & 231 \\
Tenth & 29 & 15 & 81 \\
$\quad$ Total & 36 & 14 & 1018 \\
\hline
\end{tabular}

SourcE: Calculated from Statistical Data, supra note 35, Tables 1P, 5U.

NoTE: Dismissals for want of prosecution and cases transferred were excluded from both numerator and denominator in computing the percentages of nonaffirmance. The former figure comprised all instances in which the appellate court did anything other than affirm the opinion below or dismiss the appeal. Opinions coded "affirmed in part and reversed in .part" thus were classified as nonaffirmances.

131 See Table 12 supra. 
It should not be surprising that the rate of nonaffirmance in published cases is nearly three times that figure. With few exceptions, when one court reverses another, it means that the system has not worked properly. Almost by definition, the opinion on appeal is of sufficient interest to warrant publication.

Some reversals reflect mistakes in routine matters on the part of district judges. The inability of judges to apply commonplace law correctly should be a matter of concern to all. ${ }^{132}$ Including such reversals among the unpublished opinions conceals the problem. Earlier, we discussed several examples of unpublished opinions correcting plain error by the trial judge. ${ }^{13 s}$ Another is Wesley $v$. Green. ${ }^{134}$ The trial court had dismissed a complaint because venue was improperly laid, without establishing in the record the parties' residences. Any such error, however embarrassing, should not be kept from public scrutiny. ${ }^{138}$

Reversal on routine matters may signify more than poor craftsmanship by the trial judge. It may, for example, point to uncertainty about the content of governing law. The court of appeals may not publish a reversal because, to it, the governing law was clear; such may not be the perception of others. Put differently, the unpublished opinion may clarify precedent to such a degree that the opinion should be published. Sanchez $v$. Califano ${ }^{188}$ was such a case. Its outcome turned on the allocation of the burden of proof in Social Security disability cases. The court of appeals thought the issue determined by its own published precedent. Although the court probably was correct, the precedent was hardly a

132 The major concern, of course, is a general interest in the quality of justice being dispensed. There may also be a more specific concern, however. An example would be a trial judge under consideration for elevation to a higher bench; if his reversal rate were abnormally high it might cause second thought. A high reversal rate was one of the problems that plagued Judge Carswell when he was nominated to the Supreme Court. See N.Y. Times, Mar. 6, 1970, at 24, col. 8 .

1ss See text and notes at notes 104-108 supra.

1s No. 77-2269 (4th Cir. Oct. 17, 1978). See also Dawn v. Wenzler, No. 76-3457 (9th Cir. Dec. 5, 1978) (failure to permit plaintiff to amend complaint once, which is a matter of right under Fed. R. Crv. P. 15(a)).

${ }^{133}$ A similar analysis applies to mistakes by federal law enforcement officials. Even a remand based on confession of error by the United States Attorney can be interesting enough to warrant publication. United States v. Martin, No. 79-5087 (5th Cir. June 7, 1979), contained not only such a confession, but also an observation that departures from FED. $R$. CRIM. P. 11 were "very great." Id. That is a most informative comment for anyone interested in the workings of our criminal justice system.

${ }^{136}$ No. 77-1900 (10th Cir. Jan. 11, 1979). 
model of clarity. ${ }^{137}$ Publication of Sanchez would have helped avoid similar difficulties in the future.

Reversals in routine cases may also reflect a continuing battle over the correct legal standard to apply. That is especially likely in areas where a large number of frivolous cases arise. The finder of fact naturally will seek to dispose of these quickly; the appellate court, faced with different pressures, may not be so keen. In Kidd v. Mathews, ${ }^{138}$ for example, the Sixth Circuit, in reversing a denial of black lung benefits, noted that the "Secretary [of HEW] has again used conflicting medical tests to prevent the establishment of the [statutory] presumption." "1s9 The Secretary's evident unhappiness with the governing legal standard should be exposed, so that others will be aware of the dispute and have the opportunity to comment on its merits. ${ }^{140}$

Finally, for all the reasons discussed above, reversals are quite likely to create law. Many of the decisions discussed in the analysis of separate opinions and suppressed precedent also were reversals. That observation should come as no surprise; where the reversal does not turn on correction of plain error, it is likely that the court below could not possibly have known the "true" state of the law, because it had never been declared. Thus the circuit court is forced to make law. If it does not publish its opinion, it creates a suppressed precedent.

All of the phenomena just discussed weigh strongly in favor of publication of all reversals. They tell us interesting things about the workings of our legal system, they provide helpful discussion of legal concepts, and they sometimes create-or at least clarify-precedent. Furthermore, reversal is an easy criterion to apply. Unlike most of the criteria used to select opinions for publication, reversal requires no subjective evaluation. Publishing all reversals, however, would entail a heavy cost. If all 1018 unpublished nonaffirmances in the survey year ${ }^{141}$ had been published, the number of published opinions would have increased by one-fifth. ${ }^{142}$

\footnotetext{
${ }^{187}$ See Keating v. Secretary of HEW, 468 F.2d 788, 790 (10th Cir. 1972).

138 No. 76-2530 (6th Cir. Aug. 24, 1978).

130 Id., slip op. at 2.

${ }^{140}$ See also Lykins v. MacIntosh, No. 79-6228 (4th Cir. Apr. 27, 1979) (district court erred in granting summary judgment in a prisoner's civil rights action). The standard for summary judgment in civil rights cases has been a subject of dispute in the Fourth Circuit for some time now. See Limited Publication, supra note 4, at 826 n.84.

141 See Table 13 supra.

142 There were 4699 published dispositions during the study year. See Table 1 supra.
} 
It may be, however, that some middle ground can be found, beginning with the observation that not all nonaffirmances deserve publication. One case, for example, raised questions concerning Michigan's regulation of abortion clinics under a 1974 statute. ${ }^{143}$ After the decision below and oral argument in the Sixth Circuit, Michigan revised the statute. The Sixth Circuit remanded for consideration of the constitutionality of the new law. Because remand was based upon an intervening event, passage of a new law, the opinion sheds no light on judicial practice. It is the paradigmatic opinion without value to anyone other than the litigants.

Similarly, a "pass-through" of a Supreme Court remand has such little value that its publication would be hard to justify. ${ }^{144} \mathrm{~A}$ decision not to publish a remand in light of a Supreme Court opinion in another case would be more questionable.

Finally, there is no need to publish a reversal based upon an intervening change in the law of the circuit. In that situation, the reversal tells us nothing about the quality of decision making in either court. It may not even reflect a disagreement over the content of the substantive law. ${ }^{145}$

It is impossible to tell from our sample the number of reversals whose publication would not be called for under almost any criteria. ${ }^{148} \mathrm{~A}$ rough guess, however, is that about half of the nonaffirmances center on reasons unrelated to the workings of the judiciary and the application of precedent. ${ }^{147}$ We believe that the remainder should be published. Although that would entail a significant public cost, the game should be worth the candle. To ensure proper handling, we recommend that all reversals be published unless the reversal is based upon a standard or fact not known to the tribunal below at the time that court or agency made its decision. We believe that rule will best square cost with benefit. 1978).

143 Abortion Coalition v. Michigan Dep't of Pub. Health, No. 77-1223 (6th Cir. Sept. 19,

14 A different case would be presented by substantive consideration of a Supreme Court opinion before remand to the trial court. That unquestionably should be published.

In Limited Publication, supra note 4, we recommended publication of all remands of Supreme Court decisions. Id. at 839. We now believe publication of a "pass-through" unnecessary.

${ }^{146}$ See, e.g., Gardner v. Zahradnick, No. 77-1870 (4th Cir. Sept. 29, 1978) (case held in abeyance pending decision in Gordon v. Leeke, 574 F.2d 1147 (4th Cir.), cert. denied, 439 U.S. 970 (1978); remand in Gardner required by rule established in Gordon).

146 The major problem is the cryptic nature of so many of the opinions.

${ }^{147}$ One-half is a rough estimate by the authors after reading all nonaffirmances in the sample. 
d. Summary of apparent costs. Far and away the major problem we have identified in connection with limited publication is that created by opinions that do not satisfy minimum standards. Such opinions do not give the appearance that justice has been done. More important, perhaps, shoddy opinions may reflect the quality of thought that went into the decision itself. Thoughtless opinions are a danger to be guarded against resolutely, especially given the lack of correlation between productivity and below-standard opinions. We believe every opinion can satisfy minimum standards.

Suppressed precedent is a much less significant problem. If the courts of appeals were to recall that opinions of public interest should be published, the problem would be lessened. In addition, the publication of all decisions with separate opinions, as well as many reversals, would help both to avoid suppressed precedent and to ensure the circulation of opinions that are independently of interest to the public.

3. A Hidden Cost: Disparate Impact and Certiorari Courts. A third cost, the disparate impact of limited publication, may be more pernicious, for its full effect stems from the cumulation of various devices adopted by the courts of appeals over the last decade or so to cope with their increasing caseload. An appreciation of the problem requires consideration of the interaction between limited publication and three related phenomena: (1) the disproportionately low rate of publication of opinions for some types of litigation, such as prisoners' petitions, Social Security cases, and appeals in forma pauperis; (2) the decision by the courts of appeals of a substantial number of cases without oral argument; and (3) the use by the circuit courts of central staffs of attorneys to aid in research and decision making.

Table 14 displays the subject matter of the appeals terminated during the 1978-79 Reporting Year. Most interesting among the items in the table is the comparatively high nonpublication percentages of prisoner civil rights cases, Social Security cases, and prisoner petitions in general. Such high nonpublication rates should come as no surprise, however, for those subject matter areas are the most likely to produce frivolous litigation because of the absence of disincentives to appeal. In addition, cases in those categories often involve emotional issues, pursued by litigants who seek personal vindication without any realistic expectation of legal rem- 
edy. Finally, such claims often turn on factual rather than legal issues; hence, there is less that an appellate court can do to review the decision below.

TABLE 14

Nature of Appeal

\begin{tabular}{|c|c|c|c|}
\hline $\begin{array}{l}\text { Subject Matter } \\
\text { of Appeal }\end{array}$ & $\begin{array}{c}\text { Number of } \\
\text { Published } \\
\text { Opinions }\end{array}$ & $\begin{array}{l}\text { Number of } \\
\text { Unpublished } \\
\text { Opinions }\end{array}$ & $\begin{array}{c}\text { Opinions not } \\
\text { Published } \\
(\%)\end{array}$ \\
\hline \multicolumn{4}{|l|}{ United States, Plaintiff } \\
\hline Civil Rights & 11 & 8 & \multirow{4}{*}{$\begin{array}{l}42.1 \\
75.8 \\
60.0 \\
48.1\end{array}$} \\
\hline $\operatorname{Tax}$ & 16 & 50 & \\
\hline Land Condemnation & 6 & 9 & \\
\hline Other & 110 & 102 & \\
\hline subtotal & 143 & 169 & 54.2 \\
\hline \multicolumn{4}{|c|}{ United States, Defendant } \\
\hline Prisoner Petitions & 167 & 456 & 73.2 \\
\hline Civil Rights & 94 & 176 & 65.2 \\
\hline Social Security & 92 & 305 & 76.8 \\
\hline Tort & 68 & 116 & 63.0 \\
\hline Other & 339 & 417 & 55.2 \\
\hline subtotal & 760 & 1470 & 65.9 \\
\hline \multicolumn{4}{|l|}{ Private Cases } \\
\hline Prisoner Petitions & 290 & 1038 & 72.7 \\
\hline Civil Rights & 398 & 708 & 64.0 \\
\hline Securities & 68 & 75 & 52.4 \\
\hline Labor & 91 & 116 & 56.0 \\
\hline Tort & 272 & 357 & 56.8 \\
\hline Other & 696 & 786 & 53.0 \\
\hline subtotal & 1815 & 3080 & 62.9 \\
\hline Criminal & 1320 & 1623 & 55.1 \\
\hline Total & 4038 & 6342 & 61.1 \\
\hline
\end{tabular}

SoURCE: Statistical Data, supra note 35, Tables 7, 19.

Another problem is the relatively high percentage of unpublished appeals that were filed in forma pauperis. Among unpublished opinions the in forma pauperis rate was $32 \%$, while among published opinions the rate was only $20 \% .^{148}$ Once again, the dis-

${ }^{148}$ These percentages are from Statistical Data, supra note 35, Tables 1P, 3P, 4U, 5U. 
crepancy can be explained by the higher proportion of frivolous in forma pauperis appeals because of the absence of disincentives to appeal. Nevertheless, both phenomena-the disparate publication treatment of certain types of litigation and the relatively high incidence of in forma pauperis cases on the unpublished list-give rise to concern for two reasons.

First, the disparate impact of nonpublication arguably supports a claim of denial of equal treatment by the courts. The issue has been raised before the Supreme Court, but was passed over by the Justices. ${ }^{148}$ Before this study, however, there was no hard evidence that certain classes of litigants were most likely to suffer because of limited publication. Nevertheless, even with empirical confirmation, the constitutional claim is at best colorable, because the circuit courts' practices would almost certainly pass present equal protection tests. The statistical frivolity of certain types of appeals surely provides a rational basis for the disparity, and none of the types of litigation is based on a currently recognized suspect classification justifying strict scrutiny.

Whether constitutionally justified or not, litigants in the affected classes still will believe that they have received second class justice. That is a problem, for the appearance of justice is nearly as important as the fact. ${ }^{150}$ The federal courts, which view themselves as the guardians of equal justice under law, should be uniquely sensitive to claims that their own house may not be in order.

Second, the danger of routine treatment is another threat to judicial responsibility. It is possible that a judge's mind subconsciously will run along these lines: "This is a prisoner civil rights action appealed in forma pauperis; past experience tells me there is nothing to such cases. Therefore, I don't have to think about it, and if I don't publish an opinion I won't have to sift through a meaningless record to prove the frivolity of this appeal to an uncaring public." We believe that judges zealously guard against such irresponsible decision making. But there is a danger of a judge developing a conditioned response to the surface characteristics of

11" An equal protection challenge to the Seventh Circuit's limited publication practice was made in Brief Amicus Curiae of the Chicago Council of Lawyers at 15-19, Browder v. Director, 434 U.S. 257 (1978). The Supreme Court's opinion in Browder, however, did not address that issue.

130 That may partly explain the relatively high percentage of criminal appeals (44.9\%) that are published. Many of those appeals are, no doubt, frivolous and in forma pauperis. Yet is is hard to uphold a conviction without some attempt at explanation, and once that attempt has been made there is an incentive to publish the fruits of the labor. 
certain classes of recurrent and annoying litigation. Requiring a judge to justify a decision to the public is one way to minimize that danger. ${ }^{181}$

All of the circuits provide that oral argument need not be heard for some appeals. The idea is to expedite disposition and conserve judicial resources in cases where the issues are so plain that oral argument is most unlikely to add to the quality of decision making. ${ }^{162}$ Because such "clean" cases are likely to result in routine dispositions without precedential impact, we should expect a substantial coincidence of nonpublication and denial of oral argument. In the survey year, this hypothesis proved true. Only $32 \%$ of unpublished cases were argued orally, as compared to $81 \%$ of published cases. ${ }^{158}$

Although those figures are not surprising, they lend force to the concern that nonpublication reduces the incentive for judges to probe beyond the surface of the case. That concern is particularly acute in cases submitted for decision on the briefs, for oral argument may show a court that the case has depths not apparent from the paper record. Decision without argument, coupled with the prospect of nonpublication, removes two safeguards that might lead a court to notice that the case is not in fact "routine."

Finally, there is the role played by central staff in the formulation of opinions. Over the past decade, many courts, including the United States Courts of Appeals, have added large numbers of staff law clerks to assist in preparation for argument and later disposition. ${ }^{154}$ The Ninth Circuit, for example; employed thirty staff clerks in $1978 .{ }^{155}$ Although the use of staff clerks varies widely

181 Judge Coffin addressed this point eloquently in his recent book:

A remarkably effective device for detecting fissures in accuracy and logic is the reduction to writing of the results of one's thought processes .... . Somehow, a decision mulled over in one's head or talked about in conference looks different when dressed up in written words and sent out into the sunlight .... [W] may be in the very middle of an opinion, struggling to reflect the reasoning all judges have agreed on, only to realize that it simply "won't write." The act of writing tells us what was wrong with the act of thinking.

F. Corfin, The Ways of a Judge: Replections from the Federal Appellate Bench 57 (1980).

${ }^{162}$ APpellate Justice, supra note 2, at 2-32.

183 Statistical Data, supra note 35, Tables 1P, 1U, 4P, $4 \mathrm{U}$.

154 See generally D. Meador, Apprlante Courts: Staff and Process in the Crisis of Volume (1974); Hellman, supra note 57; Lesinski \& Stockmeyer, Prehearing Research and Screening in the Michigan Court of Appeals: One Court's Method for Increasing Judicial Productivity, 26 Vand. L. Rkv. 1211 (1973); Thompson, Mitigating the Damage-One Judge and No Judge Appellate Decisions, 50 CaL. St. B.J. 476 (1975).

185 Hellman, supra note 57 , at 946. 
from court to court, in some the clerks are heavily involved in preparing preargument memoranda and draft opinions. Such procedures present an obvious danger of delegation of judicial responsibility either to the presiding judge of a panel or to the staff itself, leading to what one state judge styled the "one judge" or "no judge" decision. ${ }^{156}$

That danger increases with the concentration of staff law clerks in areas of the law where the high volume of cases makes specialization possible-even desirable, given the possibility of economies of scale. Those high-volume areas, of course, are most likely to be the ones where frivolous appeals are the most common-criminal, prisoner, and social security cases, and appeals in forma pauperis. If, as seems likely, those cases frequently are decided on submission, it can be seen how markedly the process by which many appeals are "heard" differs from the general perception of an appellate decision as based on a collegial exchange of views, marked by multiple drafts and developing ideas. ${ }^{167}$

That ideal may not often be attained. In fact, when the cumulative impact of limited publication, central staff, and the associated phenomena is assessed, it can be seen that the courts of appeals often behave much like courts with discretionary jurisdiction-like certiorari courts, in short. Suppose a petition for a writ of habeas corpus is denied by a lower court. The case is reviewed by a staff member, who makes recommendations and submits draft opinions. It is disposed of without argument by the court. That process could equally well describe a denial of certiorari by the Supreme Court or the disposition of a "routine" case by a circuit court. They certainly cannot be distinguished on the ground that denials of certiorari are unpublished and nonprecedential; so are most such "routine" circuit court decisions. A plausible distinction is that denials of certiorari typically are not accompanied by a statement of reasons, but our findings show that many of the circuit courts' unpublished opinions are similarly bereft of justification. A formal difference exists, of course, in that discretionary jurisdiction in the Supreme Court has been authorized by Congress, ${ }^{168}$ while the appellate jurisdiction of the circuit courts is mandatory. ${ }^{189}$ But when washed in the "cynical acid,"160

168 Thompson, supra note 154.

157 The best description of the ideal process is Hart, The Time Chart of the Justices,

73 Harv. L. REv. 84 (1959).

16828 U.S.C. § 1254 (1976).

150 Id. \& 1291.

${ }^{180}$ Holmes, supra note 6 , at 462. 
this formal difference evaporates. For the realist, the processes are the same. The conclusion is inescapable that, with regard to a large part of their caseload, the circuit courts have transformed themselves, contrary to congressional mandate, into certiorari courts.

Perhaps such a transformation is the necessary result of an overwhelming caseload. It may be that little has been lost, and that the quality of justice has not been diminished appreciably. Certainly some such steps are necessary to allow the continued operation of the system. Yet the cost of a changed appellate process must be recognized for what it is in order that the final price of judicial overload can be fully reckoned.

\section{Conclusion}

\section{A. A Model Rule}

Our survey of the publication habits of the circuit courts confirms that the principal benefit of limited publication is swifter justice; in addition, there may be savings in judicial efforts that in turn may be translated into gains in productivity. We have also identified two major costs: suppressed precedent and, more seriously, a marked number of low-quality opinions. Those findings challenge the critic to fashion a rule that maximizes the benefits of limited publication while avoiding as many of its costs as possible. The Model Rule that follows attempts to meet that challenge.

$$
\text { Rule _. Opinions. }{ }^{161}
$$

\section{Minimum Standards:162}

Every decision will be accompanied by an opinion that sufficiently states the facts of the case, its procedural stance and history, and the relevant legal authority so that the basis for the dis-

161 We first proposed a Model Rule for publication in Limited Publication, supra note 4 , at 837-40. The version in the text reflects lessons learned in the present study.

The Model Rule does not mention the noncitation corollary to limited publication because this study did not include any findings relative to citation. We have briefly summarized our view of noncitation rules in text and notes at notes 28-33 supra. For a more detailed analysis of noncitation rules, see Non-Precedential Precedent, supra note 4, at 119499. Similarly, this study did not focus on the circulation of unpublished opinions, so the Model Rule does not address the problem. Our views on circulation are expressed in Limited Publication, supra note 4, at 813-14.

162 Inclusion of a section on minimum standards was designed to focus judicial attention on the need to provide a minimally satisfactory explanation of why the court reached a given result. 
position can be understood from the opinion and the authority cited.

If the decision is based on the opinion below, sufficient portions of that opinion should be incorporated into the opinion of this court so that the basis for this court's disposition can be understood from a reading of this court's opinion.

2. Publication of Opinions:

a. Criteria for Publication: An opinion will be published if it:

(1) establishes a new rule of law, or alters or modifies an existing rule of law, or calls attention to an existing rule of law that appears to have been generally overlooked; ${ }^{163}$

(2) applies an established rule of law to facts significantly different from those in previous applications of the rule; ${ }^{\mathbf{1 6 4}}$

(3) explains, criticizes, or reviews the history, application, or administration of existing decisional or enacted law; ${ }^{165}$

(4) creates or resolves a conflict of authority either within the circuit or between this circuit and another; ${ }^{186}$

(5) concerns or discusses a factual or legal issue of significant public interest; ${ }^{167}$

(6) is accompanied by a concurring or dissenting opinion;

(7) reverses the decision below, unless:

a) the reversal is caused by an intervening change in law or fact, or

b) the reversal is a remand (without further comment) to the district court of a case reversed or remanded by the Supreme Court; ${ }^{188}$

1es The first clause of this rule was included in the guidelines for opinion publication suggested by the Federal Judicial Center. See Standards, supra note 17, at 15. It was included in some form in several circuit plans. See District of Columbia Circuit Plan para. a; 4TH CIR. R. 18(a)(i); 7TH CIR. R. 35(c)(1)(i); 8TH CrR. R. app. I 4(a); 9TH CIR. R. 21(b)(1). The last clause, the resurrection rule, seems to be the unique property of the Ninth Circuit. 9TH CiR. R. 21(b)(2).

1e4 See District of Columbia Circuit Plan para. e; 8Th Cir. R. app. I 4(c).

ies See District of Columbia Circuit Plan para. c; 4Th Cir. R. 18(a)(iii); 7Th Cir. R. 35(c)(1)(iii); 9TH CIR. R. 21(b)(3).

${ }^{106}$ See District of Columbia Circuit Plan para. d; 4th Cir. R. 18(a)(v); 7th Cir. R. 35(c)(1)(iv)(C); 8TH CrR. R. app. I 4(b), (f); 10TH CrR. R. 17(d)(1).

${ }^{167}$ See District of Columbia Cracutr Plan para. b; 4TH Cir. R. 18(a)(ii); 7Th Cir. $R$. 35(c)(1)(ii); 8TH CIR. R. app. I 4(d); 9TH CIR. R. 21(b)(4).

${ }_{18 s}$ Elsewhere we recommended the publication of all reversals. See Limited Publication, supra note 4 , at 839 . Here we withdraw that recommendation because it would unnec- 
(8) addresses a lower court or administrative agency decision that has been published; ${ }^{160}$ or

(9) is an opinion in a disposition that

a) has been reviewed by the United States Supreme Court, or

b) is a remand of a case from the United States Supreme Court. ${ }^{170}$

b. Publication Decision: There shall be a presumption in favor of publication. An opinion shall be published unless each member of the panel deciding the case determines that it fails to meet the criteria for publication.

3. The court recognizes that the decision of a case without oral argument and without publication is a substantial abbreviation of the traditional appellate process and will employ both devices in a single case only when the appeal is patently frivolous.

Many of the provisions of the Model Rule were suggested by existing circuit court rules. We provide textual discussion only of those provisions that were suggested primarily by the empirical study.

The most striking finding of the study is the extremely high cost of nonpublication in terms of opinion quality. Nine of the eleven circuits produced twenty percent or more below-standard opinions. In six circuits the figure was above thirty percent. ${ }^{171}$ Section 1 of the Model Rule should remedy that situation. The need for the provision is all the more apparent given that opinion quality is not correlated with productivity. ${ }^{172}$ In other words, by adopting section 1, the courts could remedy the most serious drawback of nonpublication-poor opinion quality-without reducing productivity. The case for the provision thus is very strong.

essarily increase the courts' published opinion totals by including pass-throughs and other opinions of limited precedential value.

${ }^{160}$ See 4th Crr. R. 18(a)(vi); Stxth Circuit Plan II 1; 7Th Cir. R. 35(c)(1)(v); 8Th CIR. R. app. II 4(e); 9TH CIR. R. 21(b)(5).

${ }_{170}$ A case that has generated a full United States Supreme Court opinion clearly should be published at the circuit court level-even if the publication order is retroactive. A circuit court opinion following a remand from the Supreme Court also should be published. However, if the opinion is simply a reference back to the district court, there is no need for publication.

171 See Table 10 supra.

172 See Table 11 supra. 
Section 2 of the Model Rule includes detailed publication criteria. Six of the eleven circuits currently use such detailed criteria. ${ }^{173}$ Our findings showed no positive correlation between specificity of publication criteria and the percentage of opinions published. ${ }^{174}$ Nevertheless, we favor specific criteria on the theory that the publication decision will be made in a more intelligent and consistent manner if the judges have detailed criteria to guide them. The result should be fewer cases of suppressed precedent. Additionally, our figures do not disprove the effect of specificity on publication percentages; they simply fail to prove it.

Three of the criteria warrant individual discussion. Section 2(a)(3) tries to ensure publication of opinions that reflect problems in the administration of justice or the working of case or statutory law. Judges are in a unique position to observe such problems. Any opinions that result from that advantage should be made generally available.

Section 2(a)(6) of the Model Rule calls for publication of all opinions that are accompanied by concurring or dissenting opinions. The results of the study provide strong evidence that such opinions are likely to deserve public dissemination. Of the four such opinions that we evaluated, only two were correctly left unpublished. ${ }^{176}$ Furthermore, the cost of such a provision is negligible. In the entire survey year, only thirty-eight such opinions went unpublished-about $0.5 \%$ of the total of unpublished opinions. ${ }^{176}$ This balance of costs and benefits strongly supports section 2(a)(6).

The situation is not so clear with regard to section 2(a)(7)-publication of reversals. Our findings indicate that many unpublished reversals should have been published. Some were lawdeclaring opinions and others revealed important information about the performance of lower courts and administrative agencies. On the other hand, some reversals, for instance those caused simply by an intervening change in the facts or law, should not have been published. An addition to the equation is the high cost of publishing all reversals. In the survey year, such a move would have increased the total of published opinions by twenty per-

\footnotetext{
173 See Table 3 supra.

174 See text and notes at notes 48-50 supra.

17 See text and notes at notes 116-131 supra.

176 See text at note 131 supra.
} 
cent. ${ }^{177}$ Accordingly, section 2(a)(7) is a compromise that attempts to secure the publication of only those reversals that are likely to be significant.

Section 2(b) of the Model Rule calls for a presumption in favor of publication. Our results indicate that such a presumption is likely to affect actual publication behavior, because circuits with a presumption against publication actually did publish less than circuits without such a presumption. ${ }^{178}$ Increased publication is likely to diminish the problems of suppressed precedent and poor opinion quality. Although there may be some loss in the area of swifter justice, our results do not suggest that productivity is likely to suffer. ${ }^{179}$ Section $2(b)$ also requires a unanimous decision of the panel in order not to publish.

The language of Section 3 is entirely precatory. It simply calls for judges to recognize the dangers inherent in combining several judicial "shortcuts" in a single case. There is some temptation to call for publication in all cases in which there is no oral argument or vice-versa, but the cost of such a provision is high. In the survey year, it would have more than doubled the total of published opinions. ${ }^{180}$ Our hope is that the precatory language of Section 3 will call the judges' attention to the possibility that they may be transforming their courts, without statutory authority, into certiorari courts.

\section{B. Summing Up}

The discussion of limited publication has produced numerous claims concerning the harms and benefits of the practice. This study permits an empirical evaluation of many of these claims. It is clear that limited publication produces at least one significant benefit-swifter appellate justice. The claimed benefit of savings of judicial time and effort is less clear. It is difficult to read many unpublished opinions without concluding that relatively little time and effort was spent in their production. Yet we found no positive correlation between a circuit's tendency not to publish and its pro-

${ }^{177}$ The number of published opinions for the survey year in all circuits was 4699. See

Table 1 supra. There were 1018 unpublished nonaffirmances. See Table 13 supra.

${ }^{278}$ See text and notes at notes 51-53 supra.

178 See text and note at note 65 supra.

${ }^{180}$ If the $78 \%$ of all unpublished opinions decided without oral argument, see text and note at note 153 supra, had been published, the number of published opinions would have shot up from 4699 to 10,721 . See Table 1 supra. 
ductivity. Other variables may obscure the relationship between nonpublication and productivity. Alternatively, the judges may be using the time saved to perform important but not case-related functions. Although we suspect that the time-savings hypothesis is true, we are unable to verify it empirically.

Our examination of the circuits' work has provided little to justify major concern about the problem of suppressed precedent. We did, however, find a number of cases where valuable discussions of difficulties with the law or its administration were submerged. The circuit courts could substantially remedy the problem by adhering to several of the provisions of our Model Rule.

The more significant drawback to the system is its pernicious effect on judicial responsibility. In many circuits, large percentages of the unpublished opinions failed to satisfy even minimum standards. Further, when nonpublication is combined with denial of oral argument, the result may curtail the appellate process in a way inconsistent with the mandatory appellate jurisdiction of the courts of appeals. Once again the Model Rule provides a way to reduce those costs substantially.

Perhaps the greatest danger of any procedural reform is that it will be adopted without sufficient reflection or continued without sufficient study. Although the publication plans received ample thought before their adoption and during their first several years of operation, study of the effects of the plans has almost entirely ceased. From 1973 until 1977, the plans were the subject of annual reports by the Administrative Office of the United States Courts to the Judicial Conference of the United States. The reports are no longer being made; since 1977 the study of the plans has come largely from outside of the judicial system. Clearly the courts themselves have no facilities to conduct such inquiries. The proper agency is the Administrative Office. Data on the workings of the publication plans (and other recent appellate court reforms) should be included as a regular part of the Annual Report. Perhaps after several years of such reporting, more ambitious statistical studies will be possible and will provide more conclusive answers to the questions arising out of the limited publication debate. 